\title{
Studying Autophagy in Zebrafish
}

\author{
Benan John Mathai ${ }^{1}$, Annemarie H. Meijer ${ }^{2}$ (I) and Anne Simonsen ${ }^{1, *}$ \\ 1 Department of Molecular Medicine, Institute of Basic Medical Sciences, University of Oslo, \\ Sognsvannsveien 9, 0317 Oslo, Norway; b.j.mathai@medisin.uio.no \\ 2 Institute of Biology Leiden, Leiden University, Einsteinweg 55, 2333 CC Leiden, The Netherlands; \\ a.h.meijer@biology.leidenuniv.nl \\ * Correspondence: anne.simonsen@medisin.uio.no
}

Received: 7 June 2017; Accepted: 3 July 2017; Published: 9 July 2017

\begin{abstract}
Autophagy is an evolutionarily conserved catabolic process which allows lysosomal degradation of complex cytoplasmic components into basic biomolecules that are recycled for further cellular use. Autophagy is critical for cellular homeostasis and for degradation of misfolded proteins and damaged organelles as well as intracellular pathogens. The role of autophagy in protection against age-related diseases and a plethora of other diseases is now coming to light; assisted by several divergent eukaryotic model systems ranging from yeast to mice. We here give an overview of different methods used to analyse autophagy in zebrafish—a relatively new model for studying autophagy—and briefly discuss what has been done so far and possible future directions.
\end{abstract}

Keywords: autophagy; zebrafish; GFP-Lc3; confocal microscopy; mitophagy; aggrephagy; xenophagy

\section{Introduction}

Over the past few decades we have seen a dramatic surge in research on a basic and fundamental cellular process called autophagy. Autophagy is defined as the lysosomal degradation of cytoplasmic materials (proteins, lipids, organelles, etc.), and three major types of autophagy have been described: macroautophagy, microautophagy and chaperone-mediated autophagy [1]. This review will focus on macroautophagy (hereafter referred to as autophagy), which involves the sequestration of cytoplasmic components in a double membranous structure, the autophagosome, followed by its fusion to the acidic lysosome, resulting in cargo degradation and release of simple biomolecules that can be reused for varied cellular purposes (Figure 1A). Thus, autophagy is an adaptive catabolic process leading to substrate formation for further anabolic energy-generating processes, to ultimately maintain homeostasis at the cell, tissue and organism levels.

The molecular era of autophagy started with a series of genetic screens performed on unicellular yeast in the 1990s [2-5], which were followed by the identification of respective homologs in higher eukaryotes and resulted in the characterization of more than 30 AuTophaGy-related (ATG) genes [6]. The ATG proteins essential for autophagosome formation are referred to as the 'core' autophagy machinery (Figure 1B) [7] and include: (1) the UNC-51-like kinase (ULK) complex composed of ULK1 or ULK2, ATG13, ATG101 and FIP200; (2) the class III phosphatidylinositol 3-kinase (PI3K) complex (PIK3C3), consisting of the catalytic subunit VPS34, as well as BECLIN1, p150 and ATG14L; (3) the two ubiquitin-like conjugation systems that lead to the conjugation of ATG12 to ATG5 and ATG8 to phosphatidylethanolamine (PE) in the phagophore membrane and finally (4) the transmembrane protein ATG9 [8,9]. Human ATG protein names are used here, see Table 1 for the respective zebrafish ATG orthologue names. 
Table 1. Zebrafish (Danio rerio) orthologues of human autophagy genes, with amino acid percentage identity and allele availability at the Sanger ZMP. ULK: UNC-51-like kinase; ZMP: Zebrafish Mutation Project; PE: phosphatidylethanolamine, mTORC1: Mammalian Target of Rapamycin Complex 1, AMPK: Adenosine Mono-Phosphate Kinase; ER: Endoplasmic Reticulum; PtdIns3K: Phosphatidylinositol 3-Kinase; VPS34: Vacuolar Protein Sorting 34.

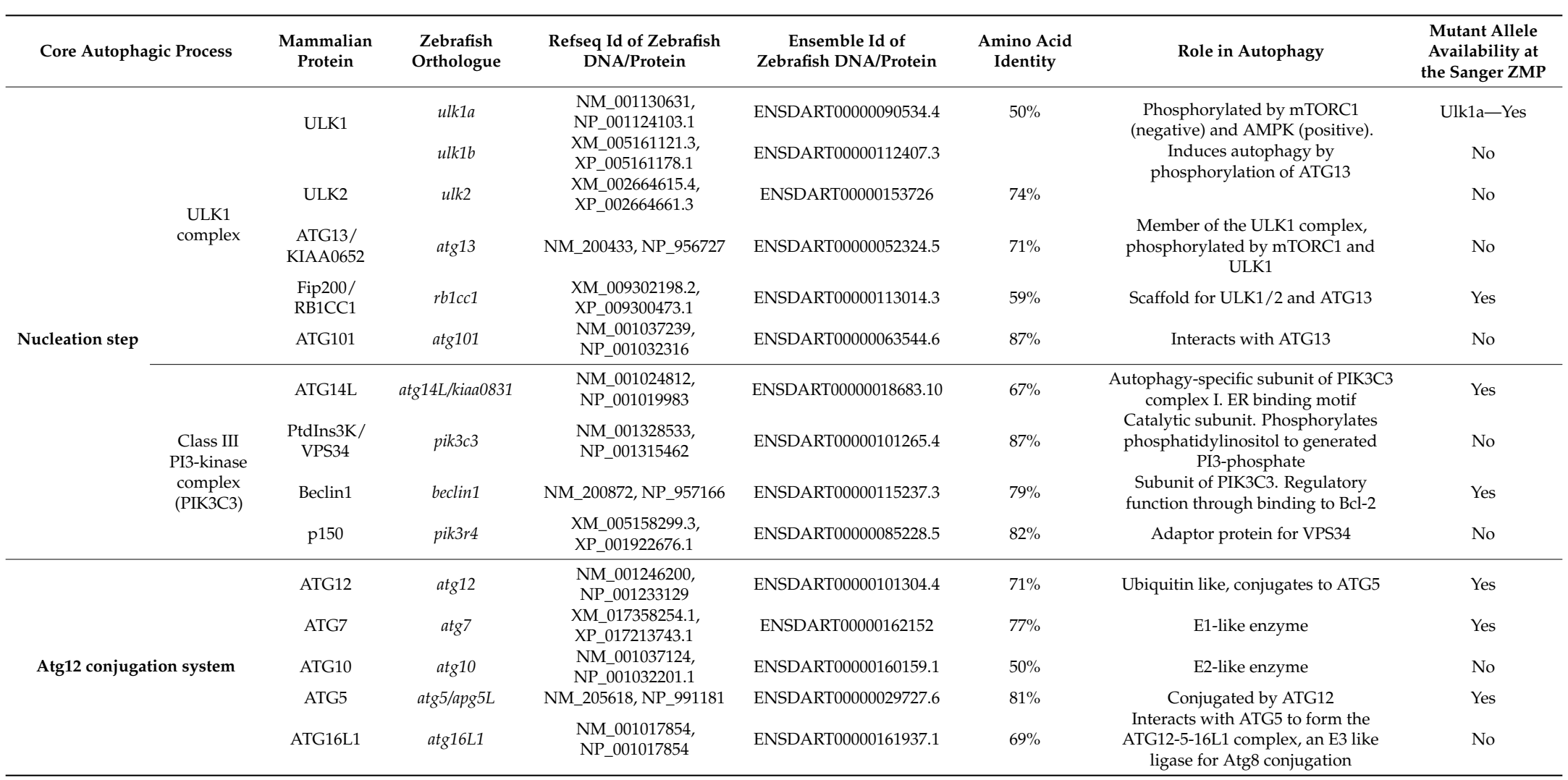


Table 1. Cont

\begin{tabular}{|c|c|c|c|c|c|c|c|}
\hline Core Autophagic Process & $\begin{array}{l}\text { Mammalian } \\
\text { Protein }\end{array}$ & $\begin{array}{l}\text { Zebrafish } \\
\text { Orthologue }\end{array}$ & $\begin{array}{l}\text { Refseq Id of Zebrafish } \\
\text { DNA/Protein }\end{array}$ & $\begin{array}{c}\text { Ensemble Id of } \\
\text { Zebrafish DNA/Protein }\end{array}$ & $\begin{array}{l}\text { Amino Acid } \\
\text { Identity }\end{array}$ & Role in Autophagy & $\begin{array}{l}\text { Mutant Allele } \\
\text { Availability at } \\
\text { the Sanger ZMP }\end{array}$ \\
\hline \multirow{12}{*}{ Atg8 conjugation system } & MAP1-Lc3A & map1-lc3a & NM_214739, NP_999904 & ENSDART00000042322.3 & $96 \%$ & \multirow{3}{*}{ Ubiquitin like, conjugates to PE } & \multirow{3}{*}{ No } \\
\hline & MAP1-Lc3B & map1-lc3b & NM_199604, NP_955898 & ENSDART00000163508.1 & $93 \%$ & & \\
\hline & MAP1-Lc3C & map1-lc3c & NM_200298, NP_956592 & ENSDART00000161846.2 & $72 \%$ & & \\
\hline & GABARAP & gabarapa & $\begin{array}{l}\text { NM_001013260, } \\
\text { NP 001013278 }\end{array}$ & ENSDART00000051547.3 & $98 \%$ & \multirow{3}{*}{ Ubiquitin like, conjugates to PE } & \multirow{3}{*}{ No } \\
\hline & GABARAPL1 & gabarapl1 & $\begin{array}{l}\text { NM_001002707, } \\
\text { NP_001002707 }\end{array}$ & ENSDART00000060037.3 & $59 \%$ & & \\
\hline & GABARAPL2 & gabarapl2 & NM_205723, NP_991286 & ENSDART00000039485.6 & $97 \%$ & & \\
\hline & ATG4A & atg $4 a$ & $\begin{array}{l}\text { NM_001024434, } \\
\text { NP_001019605 }\end{array}$ & ENSDART00000026666.10 & $70 \%$ & \multirow{3}{*}{$\begin{array}{l}\text { Atg8 C-terminal hydrolase, } \\
\text { deconjugating enzyme }\end{array}$} & Yes \\
\hline & ATG4B & atg $4 b$ & $\begin{array}{l}\text { NM_001089352, } \\
\text { NP_001082821 }\end{array}$ & ENSDART00000121558.3 & $73 \%$ & & No \\
\hline & ATG4C & $\operatorname{atg} 4 c$ & $\begin{array}{l}\text { NM_001002103, } \\
\text { NP_001002103 }\end{array}$ & ENSDART00000051779.3 & $59 \%$ & & Yes \\
\hline & ATG4D & atg $4 d a$ & $\begin{array}{l}\text { XM_009294436.2, } \\
\text { XP_009292711.1 }\end{array}$ & ENSDART00000152289.2 & $50 \%$ & \multirow[b]{3}{*}{ E2-like enzyme } & No \\
\hline & & $a \operatorname{atg} 4 d b$ & & ENSDART00000172196 & $50 \%$ & & No \\
\hline & ATG3 & atg3 & NM_200022, NP_956316 & ENSDART00000041304.7 & $82 \%$ & & No \\
\hline \multirow{8}{*}{$\begin{array}{l}\text { Other core Atg proteins during } \\
\text { autophagosome formation }\end{array}$} & ATG2A & $\operatorname{atg} 2 a$ & $\begin{array}{l}\text { XM_009307758.2, } \\
\text { XP_009306033.1 }\end{array}$ & ENSDART00000172444.1 & $55 \%$ & \multirow[t]{2}{*}{ Proper closure of autophagosome } & No \\
\hline & ATG2B & $\operatorname{atg} 2 b$ & XP_001340508.3 & ENSDART00000155615 & $42 \%$ & & No \\
\hline & ATG9A & $\operatorname{atg} 9 a$ & $\begin{array}{l}\text { NM_001083031, } \\
\text { NP_001076500 }\end{array}$ & ENSDART00000065411.6 & $71 \%$ & Transmembrane protein on the & No \\
\hline & ATG9B & atg $9 b$ & $\begin{array}{l}\text { NM_001320078, } \\
\text { NP_001307007 }\end{array}$ & ENSDART00000147499.3 & $49 \%$ & \multirow{5}{*}{$\begin{array}{l}\text { Phosphatidyl-insolitol 3-phosphate } \\
\text { PI(3)P-binding proteins }\end{array}$} & No \\
\hline & WIPI1 & wipi1 & NM_200391, NP_956685 & ENSDART00000059533.4 & $71 \%$ & & Yes \\
\hline & WIPI2 & wipi2 & $\begin{array}{l}\text { NM_001327789, } \\
\text { NP_001314718 }\end{array}$ & ENSDART00000134026.2 & $82 \%$ & & Yes \\
\hline & $\begin{array}{l}\text { WIPI3/ } \\
\text { WDR45B }\end{array}$ & wipi3/wdr45b & NM_200240, NP_956534 & ENSDART00000152327.2 & $96 \%$ & & No \\
\hline & WDR45 & wipi4 & NM_200231, NP_956525 & ENSDART00000130229.2 & $90 \%$ & & No \\
\hline \multirow{7}{*}{ Autophagy receptor proteins } & NCOA4 & ncoa4 4 & NM_201129, NP_957423 & ENSDART00000017052.8 & $38 \%$ & $\begin{array}{l}\text { Autophagy cargo receptor required } \\
\text { during iron homeostasis }\end{array}$ & No \\
\hline & $\begin{array}{l}\text { SQSTM1/ } \\
\text { p62 }\end{array}$ & sqstm1/p62 & $\begin{array}{l}\text { NM_001312913, } \\
\text { NP_001299842 }\end{array}$ & ENSDART00000140061.2 & $44 \%$ & Autophagy cargo receptor & No \\
\hline & OPTN & optn & $\begin{array}{l}\text { NM_001100066, } \\
\text { NP_001093536 }\end{array}$ & ENSDART00000014036.10 & $41 \%$ & Autophagy cargo receptor & No \\
\hline & $\begin{array}{l}\text { CALCOCO2/ } \\
\text { NDP52 }\end{array}$ & calcoco 2 & $\begin{array}{l}\text { NM_001020741, } \\
\text { NP_001018577 }\end{array}$ & ENSDART00000152964.2 & $30 \%$ & $\begin{array}{l}\text { Autophagy cargo receptor during } \\
\text { xenophagy and mitophagy }\end{array}$ & No \\
\hline & NBR1 & $n b r 1$ & $\begin{array}{l}\text { NM_001305595, } \\
\text { NP_001292524 }\end{array}$ & ENSDART00000133048.2 & $38 \%$ & Autophagy cargo receptor & Yes \\
\hline & TAX1BP1 & tax1bp1a & $\begin{array}{l}\text { NM_001346178, } \\
\text { NP_001333107 }\end{array}$ & ENSDART00000171664.1 & $44 \%$ & $\begin{array}{l}\text { Autophagy cargo receptor during } \\
\text { mitophagy }\end{array}$ & Yes \\
\hline & & $\operatorname{tax} 1 b p 1 b$ & NM_212664, NP_997829 & ENSDART00000040727.7 & $52 \%$ & Autophagy cargo receptor & Yes \\
\hline
\end{tabular}




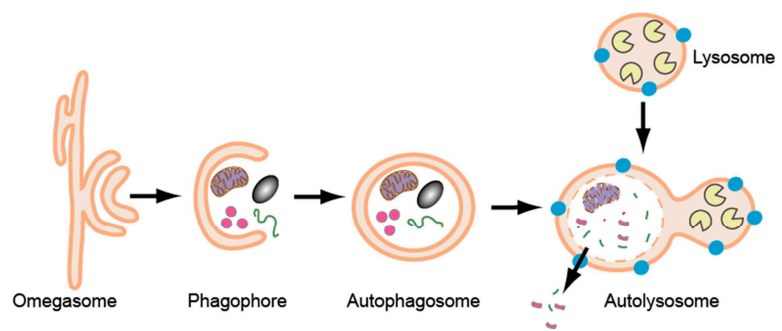

(A)

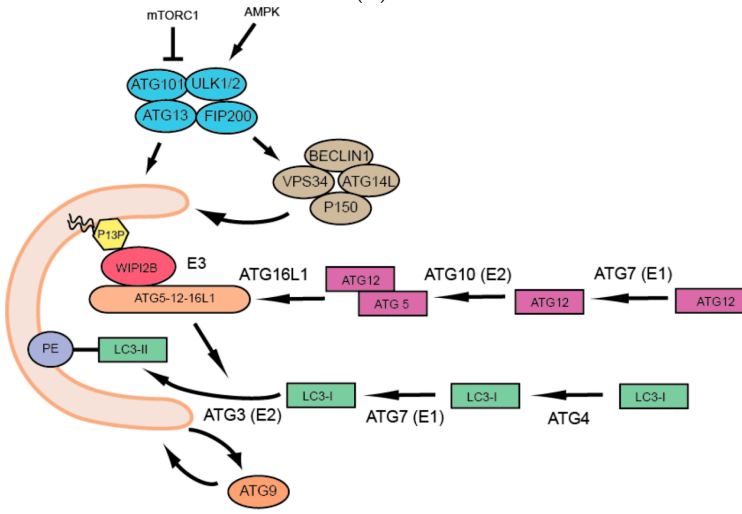

(B)

Figure 1. (A) Schematic overview of the process of macroautophagy; (B) Schematic overview of the core autophagic proteins involved in autophagosome biogenesis.

In addition to these core autophagy proteins, the regulation and execution of the pathway is tightly controlled by a large number of proteins and lipids and we are only beginning to understand how their interconnections are regulated in time and space under various metabolic conditions and in different tissues. Dysfunctional autophagy is closely associated with tumorigenesis [10,11], immune disorders [12], neurodegeneration and aging [13], infectious diseases [14] and diabetes [15]. Thus, a detailed understanding of the molecular mechanisms involved in autophagy may open doors to various therapeutic approaches against diseases where autophagy plays an indispensable role.

Our understanding of how autophagy is regulated under different physiological and pathological conditions is largely based on research performed in different tractable animal model systems such as the fruit fly Drosophila melanogaster [16,17], nematode Caenorhabditis elegans [18], the mouse Mus musculus [19,20], oysters [21] and Dictyostelium discoideum [22]. Recently, there has been an exponential interest in using zebrafish (Danio rerio) for varied research owing to the immense advantages that it offers. The small size, high fecundity, external fertilization, transparent embryos, rapid development, and genetic tractability of zebrafish make it highly desirable for basic science and translational high throughput research [23].

We here review the current literature and the methods used to study autophagy in zebrafish, including DNA, RNA and protein-based methods. We also discuss different types of selective autophagy, with emphasis on mitophagy, xenophagy and aggrephagy and how these can be studied in zebrafish. Finally, we provide detailed information about different antibodies, chemical reagents and reporter lines that have been used to analyze autophagy in zebrafish and discuss how current methods could be improved to better understand autophagy in zebrafish.

\section{Zebrafish Autophagy Genes}

The identification of the zebrafish as a genetically tractable organism in the 1980s led to its immense usage in the 1990s, whereby a large number of mutations giving rise to specific phenotypes were discovered through large-scale mutagenesis screens [24]. However, this alone was insufficient to throw light on various rare and common human disorders as a high-quality zebrafish genome 
sequence and complete annotation of zebrafish protein-coding genes with identification of their human orthologues was limited. The genome of the zebrafish has now been published as a well-annotated reference genome, providing key insights into the use of this vertebrate as a desirable model to mimic human disease states. In total, $84 \%$ of human disease-associated genes have at least one obvious zebrafish orthologue [25-27].

To be able to alter or modulate autophagy genetically in zebrafish, it is critical to delineate the representative ATG zebrafish orthologues from its yeast or mammalian counterparts. We searched for human ATG proteins from National Centre for Biotechnology Information (NCBI) and blasted their respective amino acid sequences against Danio rerio's (taxid: 7955) reference proteins as a search set. The hit with highest query coverage and smallest E-value was selected to be an orthologue. We also compared the sequence with that annotated in the Ensemble genome browser. A detailed account of the core ATG proteins (mammalian) and their respective zebrafish orthologue with Refseq IDs and Ensemble IDs have been tabulated (Table 1). The overall amino acid identity between human and zebrafish core autophagy proteins range between 40 and 96\% (Table 1).

\section{Genome Editing Techniques}

Genome editing, or the idea of introducing a desired change to the genomic DNA sequence, is currently driving a revolution in the medical field with the introduction of the Clustered Regularly Interspaced Short Palindromic Repeats (CRISPR)/CRISPR Associated Protein 9 (Cas9) technology [28-30]. An ideally desirable genome editing tool would edit any genomic locus with high efficiency, specificity and with little or no off-target effects. The basic process of nuclease-based genome editing is to create a specific double-strand break (DSB) in the genome and then allow the cell's own endogenous repair machinery to repair the break, by either non-homologous end-joining (NHEJ) or by homology-directed repair (HDR). The different techniques of genome editing used in zebrafish (CRISPR/Cas9, transcription activator-like effector nucleases (TALENs) and zinc finger nucleases) have been extensively reviewed elsewhere [31-37]. We will here discuss how genome editing could help drive the field of zebrafish autophagy.

\subsection{CRISPR/Cas9 Mutagenesis}

The CRISPR/Cas9 technology has been widely adopted in the zebrafish community and has already come a long way from the first knock-out [38], to high-throughput mutagenesis screens [33], conditional knockout [39], multiplex knockout [40,41] and to targeted insertion of DNA elements [42]. It would be highly desirable to apply systematically all of these techniques into understanding the precise role of autophagy proteins in zebrafish development, physiology and pathology.

Briefly, CRISPR/Cas9-mediated genome editing in zebrafish is facilitated by the microinjection of a "short guide-RNA" (sgRNA) and Cas9 endonuclease protein into zebrafish embryo (at 1 cell stage), wherein the Cas endonuclease protein, forms a complex with the sgRNA molecule (now called the Cas9 holoendonuclease). Cas9 holoendonuclease or the corresponding RNAs (sgRNA + Cas9 messenger RNA (mRNA)) can be injected. The target DNA sequence, in addition to being complementary to the gRNA molecule, should also have a "protospacer-adjacent motif" (PAM), that is required for compatibility with the particular Cas protein being used. Once mobilized to the target DNA site, the Cas9 holoendonuclease generates a double-strand break (DSB), which can be used to create a knock-out or add a specific function to a gene (targeted knock-in). Autophagy can be manipulated by injecting sgRNA against the core autophagy genes (Table 1) together with either Cas9 mRNA or protein. It is very important to minimize or best, to negate, mutagenesis of an incorrect gene (off-target effect). Step-by-step protocols describing how to design an efficient sgRNA and the heuristic rules surrounding it, purifying Cas9 mRNA or using commercial Cas9 protein along with sgRNA have been reviewed previously $[43,44]$. The transparency of zebrafish larvae makes zebrafish highly desirable to use for generation of reporter lines. CRISPR/Cas9 can be used to tag core autophagy genes endogenously by "knocking-in" a reporter DNA element upstream/downstream of the autophagy 
gene of interest, e.g., to generate a fusion protein at an endogenous locus. This is highly desirable in the study of autophagy, opening up the prospect of "double-tagging" an autophagy protein or a cargo of interest and following their degradation kinetics. "Double-tagging" is based on the principle of using tandem fluorescent tags, where one will be quenched (e.g., green fluorescent protein (GFP)) upon delivery to the acidic lysosome. CRISPR/Cas9-mediated genome editing can also used to ablate a particular gene in a specific tissue or at a particular developmental time-point. As an example, LoxP sites can be "knocked-in" to flank an autophagy gene of interest and later by using the cre recombinase, the gene can be inverted or excised, thereby creating a complete knock-out. This is suitable for genes whose knockout can be embryonically lethal.

The use of CRISPR/Cas9-based targeted mutagenesis for deriving stable transgenic zebrafish or zebrafish knockout autophagy lines is in its initial phase. So far only one study has used this system to create mutant lines. CRISPR/Cas9-based mutagenesis in spns1 and atp6v0ca genes induced premature autophagosome-lysosome fusion marked by insufficient acidity leading to developmental senescence and death [45]. spns1 is thought to function as a lysosomal $\mathrm{H}^{+}$-carbohydrate symporter, which functions at a late and terminal stage of autophagy [46,47]. atp6r0ca encodes a sub-unit of the vacuolar-type $\mathrm{H}^{+}$-ATPase (v-ATPase) that counteracts spns 1 ablation effects in zebrafish. It is highly likely that we will soon see increasing use of CRISPR/Cas9 technology to modulate autophagy in zebrafish.

\subsection{TALENS and ZFNS}

Since the introduction of CRISPR/Cas9 for genome editing in zebrafish, the use of TALENs and ZFNs, which were used before for genome editing [36,37] have taken a back seat (for a review of these methods see references). The use of TALENs and ZFNs to study autophagy in zebrafish is limited. TALEN-mediated mutation of the nuclear hormone receptor $n r 1 d 1$ was shown to have a positive effect on autophagosome-autolysosome number and lead to upregulation of ATG genes. nr1d1 mutants were also shown to affect the circadian clock by significantly upregulating the circadian clock genes, leading to the conclusion that the circadian clock regulates autophagy rhythms in zebrafish larvae [48].

\subsection{Transient Gene Knockdown by Morpholino Oligonucleotides}

Morpholino oligonucleotides or morpholinos, first developed by Dr. James Summerton, are oligomers of 25 morpholine bases that are targeted via complementary base pairing to the mRNA of interest. They silence the gene by either blocking the translational start site from the ribosomal machinery or by blocking the splice sites (donor/acceptor), thereby interfering with the binding of spliceosome components [49,50]. Morpholinos can be used to interrogate pathways and associate genes with a phenotype and this can be done easily by just injecting an optimal volume of the morpholino solution into the yolk sac of a zebrafish embryo at the 1-4 cell stage. Morpholinos provide precise spatial targeting of multiple gene products [51] and are extremely useful for silencing and analyzing maternal gene expression [52]. However, a drawback of morpholinos is the relatively frequent off-target effects. Off-target effects are often caused by the induction of p53 that leads to apoptosis, but can also be p53-independent $[53,54]$. Inconsistencies between morphant and CRISPR mutant phenotypes have been seen in some studies [54], whereas others have shown that such inconsistencies can be explained by a compensating gene that is upregulated in the mutants, but not in the morphants [55]. Recent reports point out off-target single nucleotide variations (SNVs) in CRISPR-repaired mice, fished out via whole genome sequencing (WGS) [56]. Therefore, if used with the appropriate controls, morpholinos remain a useful tool [57].

Morpholinos have been employed vigorously to analyze autophagy in zebrafish and have provided valuable insight into the role of autophagy in development and disease. Knockdown of Atg5, Atg7 and Beclin1 [58,59], Atg4da [60], Ambra1a and Ambra1b [61,62] all show an important role of autophagy during embryogenesis. One of the common phenotypes seen consistently among these studies is a cardiac defect, indicating a very specific role of autophagy in cardiac 
morphogenesis/function, in alignment with previous studies on rodents [63]. Moreover, knockdown of optineurin, an ubiquitin-binding autophagy-receptor protein, was shown to cause motor axonopathy due to defective autophagic clearance of accumulated SOD1-G93A aggregates [64], defective vesicle trafficking in the axons [65], and increased susceptibility to Salmonella enterica infection [66]. Morpholino-mediated depletion of Spns1, a lysosomal transporter, was found to upregulate embryonic cellular senescence [46] and this was counteracted by the depletion of the lysosomal v-ATPase, which together suppresses developmental senescence and increases life-span [45]. Transient depletion of p62/sqstm1, another ubiquitin-binding autophagy receptor protein, in zebrafish embryos was shown to increase susceptibility to Shigella flexneri and Mycobacterium marinum in the host, indicating the role of autophagy against bacterial infection $[67,68]$. In another study involving the knockdown of p62/sqstm 1 in zebrafish, it was seen that the ablation caused a specific locomoter phenotype characterized by a specific axonopathy of descending motor neuron projections [69]. Sorting nexin 14 knockdown in zebrafish larvae led to neuronal cell death (neurodegeneration) associated with defective autophagic degradation, ultimately resulting in cerebellar ataxias [70].

Several reports have indicated an indirect escalation or enervation of autophagy in zebrafish models of gene ablation by morpholinos. Zebrafish embryos depleted of the phosphatidylinositol 3-phosphatase MTMR14 (better known as Jumpy) showed an increase in autophagy at 1 day post fertilization (dpf) [71], consistent with previous results in mammalian cells, showing that MTMR14 dephosphorylates PI(3)P in the early autophagic membranes, thereby inhibiting autophagy [72]. We recently found that the PX domain protein $\mathrm{Hs} 1 \mathrm{bp} 3$ also regulates the formation of autophagosomes by a novel negative-feedback mechanism on membrane lipids. Morpholino-mediated depletion of Hs1bp3 in zebrafish embryos caused an increase in GFP-Lc3 puncta, which was rescued by co-injection of mRNA encoding the human HS1BP3 protein, thereby validating the conserved role of Hs1bp3 as negative regulator of autophagy in vivo [73] (Figure 3).

In another study, depletion of collagen VI (COLVI), a protein crucial for structural integrity, cellular adhesion, migration and survival, resulted in reduced lipidation of Lc3 and reduced expression of Beclin1, suggesting an overall inhibition of autophagy in these morphants, ultimately leading to muscle dysfunction [74]. The role of autophagy in survival of hematopoietic cells was observed in a disrupted ribosome biogenesis model of zebrafish where rps19 was ablated using translation morpholino $[75,76]$. A detailed list of all morpholinos used to analyze autophagy in zebrafish has been included in another review [77].

\subsection{Mutations}

In a major effort to generate mutant zebrafish lines, Christiane Nüsslein-Volhard and Wolfgang Driever orchestrated two of the largest mutagenesis screens ever performed in zebrafish [24,78]. These studies brought forth about 1500 mutations in more than 400 genes, but neither these original screens nor any later screens have revealed a mutant allele of a core autophagy gene. One possible reason for this could be that such mutations would be early embryonic lethal or it might be explained by the late onset of autophagy-related phenotypes in zebrafish.

A high quality sequence assembly of the zebrafish genome was initiated by the Sanger Institute (UK) in 2001 and completed in 2013 [25]. The Sanger Institute also initiated a systematic effort called the Zebrafish Mutation Project (ZMP) [26], which has created mutant alleles in over 16,000 protein-coding genes, including a number of core autophagy genes (Table 1). Using such autophagy mutant lines would provide valuable insight into the role of autophagy in physiological processes.

\section{RNA-Based Analysis}

Autophagy is known to be tightly regulated by posttranslational modifications of autophagy proteins (e.g., phosphorylation of ULK1 by mTORC1 and AMPK oppositely regulate the activity of the ULK1 complex) and by regulation of protein levels. But in order to obtain a real estimation of autophagy it is necessary to also monitor their mRNA levels [79]. It is however important to note 
that increased mRNA levels of autophagic genes should not be interpreted as increased autophagy, as it can be a compensatory mechanism. A detailed list of primers used to assess the expression of autophagy-related genes by quantitative real-time PCR (qRT-PCR) in zebrafish has been reviewed recently [77]. Zebrafish embryos and larvae are also very suited for whole mount in situ hybridization (WISH), which provides information about the spatial expression of a particular gene in the whole organism. This does not aid much in answering questions on autophagy activity, but still could help analyze the spatial arrangement of autophagy genes under certain conditions. WISH expression patterns are systematically catalogued in the zebrafish information network (ZFIN) database (zfin.org). mRNA sequencing is a sensitive and accurate method for analyzing the transcriptomes of disease states and/or of biological processes. Prior to the activation of the zebrafish embryo genome, maternally-derived mRNA regulate early development in zebrafish [80,81]. This occurs at the 10th cell division ( $\sim 3.5 \mathrm{~h}$ post-fertilization) when the zebrafish zygotic genome gets activated, also known as the mid-blastula transition (MBT) [82]. Mathavan and colleagues applied mRNA deep sequencing (mRNA-seq) to gain a comprehensive understanding of all transcriptional processes occurring from the unfertilized egg to early gastrulation [83]. We procured the raw data and fished for "core autophagy genes" in the data (available in the Gene Expression Omnibus (GEO) database, accession number GSE22830). Almost all of the core autophagy genes are expressed maternally at quite low levels, except for map1-lc3c which is expressed at high level from the oocyte to MBT. Interestingly, while the expression of map1-lc3c tapers off post MBT, there is a correspondingly strong increase in map1- $l c 3 b$ expression levels at MBT, suggesting that map1-lc3c plays an important role during the early embryonic cell divisions, with map1-lc3b being more important later. Wipi2 is consistently highly expressed across the early cell divisions to gastrulation (Figure 2). Several other mRNA-seq datasets are publicly available in the GEO database, also covering other later development stages. For example, in a developmental time series from 1 to 6 days post fertilization it was shown that the autophagy modulator gene dram 1 is upregulated during Mycobacterium marinum infection [84].

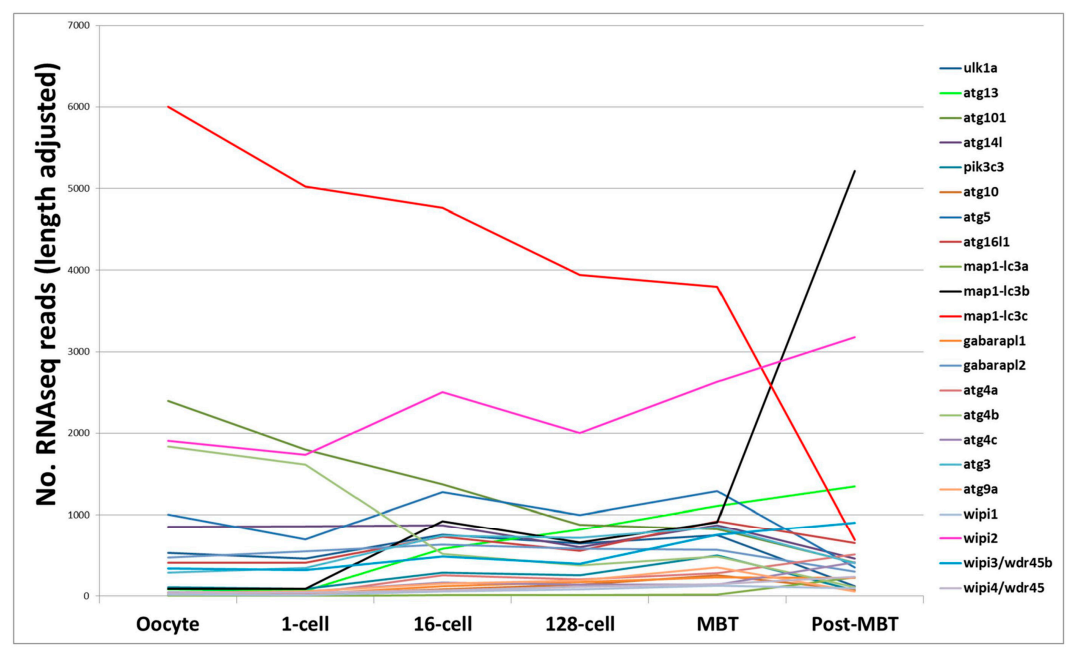

Figure 2. Messenger RNA sequence (mRNA-seq) analysis. Line plot of core autophagy gene transcripts analyzed by mRNA-seq in zebrafish embryos from the oocyte stage to post-mid blastula stage transition.

\section{Protein-based analysis}

\subsection{Fluorescence Microscopy}

The most widely used marker to study autophagy is Atg8/Lc3, as this protein becomes conjugated to $\mathrm{PE}$ in the autophagic membrane upon induction of autophagy and remains bound throughout the pathway [85]. The lipidated form of Lc3 (called Lc3-II) can be visualized as cytoplasmic puncta by immunofluorescence microscopy or by a shift in molecular weight when analyzed by sodium dodecyl 
sulfate-polyacrylamide gel electrophoresis (SDS-PAGE) (described below). To analyze Lc3 lipidation in vivo, it is common to measure the increase in Lc3 puncta, using models where the $\mathrm{N}$-terminus of Lc3 is tagged to a fluorescent reporter protein such as GFP. In zebrafish, GFP-Lc3 can be visualized in vivo during development due to the transparency of zebrafish embryos (Figure 3). Transgenic GFP-Lc3 and GFP-Gabarap fish have been generated [86] and are described in more detail below. Zebrafish larvae beyond $2 \mathrm{dpf}$ develop pigments, which would be a hindrance for normal fluorescent microscopy. However, larvae can still be visualized for cellular activities in transgenic reporter lines by supplementing the media with 1-phenyl-2-thiourea (PTU), which inhibits melanogenesis or by using zebrafish strains that have mutations affecting pigment production [87]. Fusion of autophagosomes with lysosomes can be readily detected in vivo by the addition of LysoTracker Red to fish media prior to visualization [86].
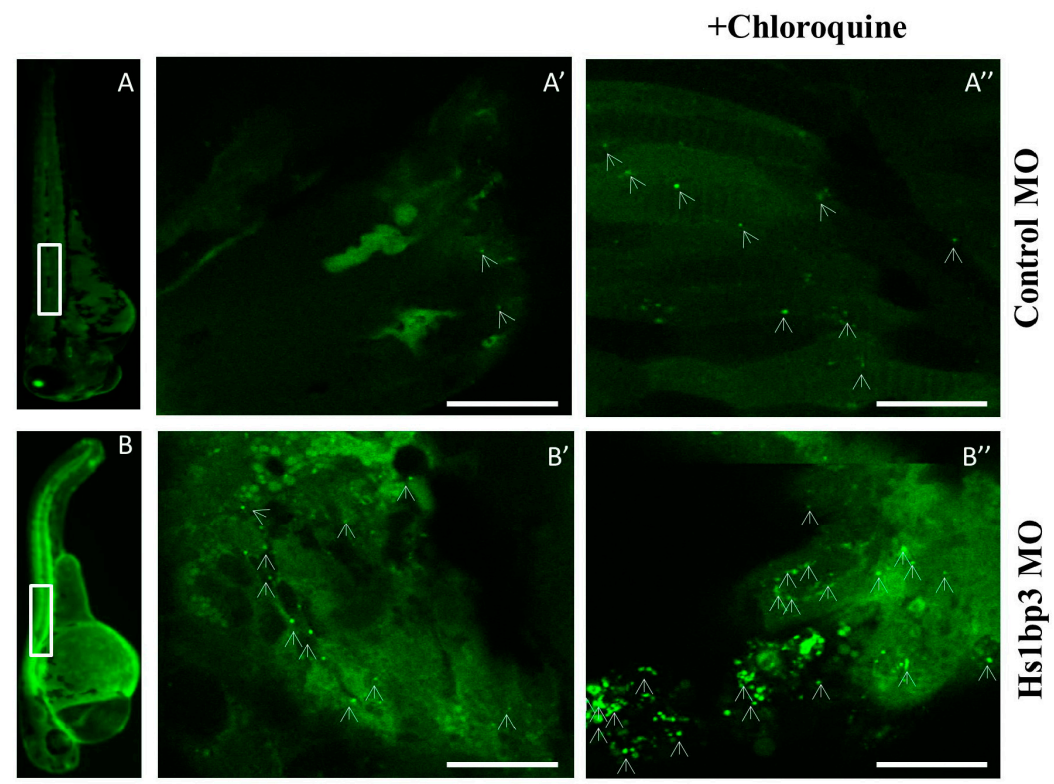

Figure 3. Confocal imaging of $\operatorname{Tg}(\mathrm{CMV}$ :GFP-Lc3). Representative confocal images of GFP-Lc3 puncta (autophagosomes) in the trunk area of GFP-Lc3 transgenic zebrafish embryos injected with control morpholino or Hslbp3 translational-blocking morpholino and imaged at 2 days post fertilization (dpf) with or without pre-treatment with chloroquine $(10 \mathrm{mM})$ for $6 \mathrm{~h}$. Scale bars, $10 \mu \mathrm{M}$ for the confocal images. Panel A, B shows the whole zebrafish larvae at 2 days post fertilization highlighting the trunk area chosen for confocal imaging; Panel $\mathrm{A}^{\prime}, \mathrm{A}^{\prime \prime}, \mathrm{B}^{\prime}, \mathrm{B}^{\prime \prime}$ shows respective confocal images.

Fluorescence methods (reporter lines or immunofluorescence (IF)) are more sensitive and quantitative as compared to molecular techniques like western blotting. Increased autophagic activity is usually marked by a significant change in the number of fluorescent puncta. However, it is very important to note here that an increase in GFP-Lc3 puncta can be caused by an increased flux or by impairment of autolysosome formation [79]. Therefore, proper flux experiments must be done (e.g., stimuli in the absence or presence of lysosomal inhibitors) to be able to conclude. While quantifying live in vivo images from a reporter line like the GFP-Lc3 line, it has to be done on a 'per-cell area' basis rather than simply using the total number (or percentage) of cells displaying puncta. This point is important as in zebrafish larvae which have a constant supply of nutrients from the yolk-sac, there could be some cells displaying a basal level of GFP-Lc3 puncta under "fed" conditions. In situations where endogenous Lc3 could be stained with a specific antibody, it is important to counterstain the nuclei with DAPI or Hoechst and then quantify puncta on a 'per-cell' basis. Another important caveat to be noted when using GFP-Lc3 is its tendency to bind to aggregates, especially when working with protein-aggregation models or when overexpressed [88]. Interpretation 
of autophagy in these models should be done by negating off the background fluorescence by having an untagged internal GFP control [79] or by the use of a C-terminal glycine mutant GFP-LC3 that is defective in ubiquitin-like conjugation with phosphatidylethanolamine, (GFP-LC3 ${ }^{\mathrm{G} 120 \mathrm{~A}}$ as a negative control) [89] or by another fluorescent protein tandemly fused to GFP, e.g., red fluorescent protein (RFP) (GFP-RFP-Lc3). Using lysosomal dyes (e.g., LysoTracker Red) in tandem with GFP-Lc3 is another useful approach $[46,86,90]$. Here the colocalization of GFP-Lc3 and LysoTracker can be used as an indicator of autophagy.

The use of transgenic zebrafish models to study autophagy was kick-started by Klionsky and co-workers who developed the $\mathrm{Tg}(\mathrm{CMV}$ :GFP-Lc3) and $\mathrm{Tg}(\mathrm{CMV}$ :GFP-Gabarap) transgenic lines [86]. The $\mathrm{Tg}(\mathrm{CMV}$ :GFP-Lc3) line has been used in various studies giving important insights into the functional significance of autophagy and autophagy modulators in vivo [46,58,67,68,73,91-94]. $\operatorname{Tg}$ (fabp10:EGFP-Lc3) and $\operatorname{Tg}(\mathrm{T} \alpha \mathrm{CP}: \mathrm{GFP}-\mathrm{Lc} 3)$ were used recently for looking into autophagy in the liver [95] and in photoreceptors [90], respectively.

The introduction of the tandem fluorescent tagged Lc3 in mammalian cell lines [96] opened up for the possibility of making similar tandem tagged (e.g., RFP/mCherry-GFP) reporter lines in model organisms. As briefly mentioned above, the underlying principle of using a tandem tag to study autophagy is based on the $\mathrm{pH}$ sensitivity of GFP, with the GFP signal being quenched when the tagged protein reaches the acidic environment of the lysosome, while the red signal (RFP/mCherry) is stable. Thus, the ratio between yellow (autophagosomes) and red (autolysosomes) signal can readily be used to quantify autophagic flux. A recent study used a transgenic zebrafish line expressing the tandem tag for Lc3 under the control of a photoreceptor promoter, $\mathrm{Tg}(\mathrm{T} \alpha \mathrm{CP}$ :mCherry-GFP-map1lc3b) [97]. The tandem-tag principle can be exploited to generate other zebrafish reporter lines (by tandem-tagging selective autophagy cargo or autophagic receptors) that would contribute to our understanding of autophagy and the mechanisms underlying its role in zebrafish development and physiology.

As mentioned earlier, one should be cautious when interpreting Lc3 data. An increase in Lc3 levels should be validated by estimating the total autophagic flux, by e.g., treating samples with and without lysosomal inhibitors, such as Bafilomycin A1 or chloroquine (Figure 3). There are however reports that lysosomal inhibitors could inhibit mTORC1 and induce "unwanted" autophagy [98-100]. Taking these loopholes into consideration, the Mizushima group recently constructed a novel probe, GFP-Lc3-RFP-Lc3 $\Delta G$, which they tested in zebrafish as well [101]. The transgenic zebrafish line that ubiquitously expresses $\mathrm{Tg}(\mathrm{GFP}-\mathrm{Lc} 3-\mathrm{RFP}-\mathrm{Lc} 3 \Delta \mathrm{G})$ aided robust assessment of autophagic flux by the measurement of the GFP/RFP ratio. The underlying principle here is that the reporter probe will be cleaved by endogenous Atg 4 proteases into equimolar amounts of GFP-Lc3 and RFP-Lc3 $\Delta$ G, a mutant unable to become conjugated to the autophagy membrane. Thus, while GFP-Lc3 becomes lipidated and degraded by autophagy, the RFP-Lc $3 \Delta G$ remains in the cytosol, serving as an internal control. Autophagic flux can then be estimated by calculating the GFP/RFP signal ratio.

Fluorescent reporter lines of other autophagy core components or probes to detect autophagic membranes would also be desirable. The zebrafish transgenic reporter lines $\operatorname{Tg}(\mathrm{T} \alpha \mathrm{CP}$ :YFP-2XFYVE) and $\operatorname{Tg}(T \alpha C P$ :tRFP-t-2XFYVE) are examples of the latter. The FYVE domain is a conserved protein motif characterized by its ability to bind with high specificity to phosphatidylinositol 3-phosphate (PI(3)P), a phosphoinositide highly enriched in early endosomes, but also detected in early autophagic structures and found to be important for autophagy [102]. These zebrafish transgenic reporter lines ( $\mathrm{Tg}(\mathrm{T} \alpha \mathrm{CP}$ :YFP-2XFYVE) and $\mathrm{Tg}(\mathrm{T} \alpha \mathrm{CP}$ :tRFP-t-2XFYVE)) were recently used to characterize endolysosomal trafficking events upon ablation of the polyphosphoinositide phosphatase, Synaptojanin1 (synj1) in cone photoreceptors [97]. A summary of the zebrafish autophagy reporter lines used in zebrafish can be found in Table 2. 
Table 2. Constitutive and transient reporter constructs used to study autophagy in zebrafish.

\begin{tabular}{|c|c|c|}
\hline Reporter & Expression & Reference \\
\hline Tg(CMV:GFP-Lc3) & Ubiquitous & [86] \\
\hline $\operatorname{Tg}(\mathrm{CMV}: G F P-G a b a r a p)$ & Ubiquitous & [86] \\
\hline $\operatorname{Tg}(\mathrm{pT} 2-\mathrm{mCherry-Sqstm} 1)$ & Ubiquitous & {$[45]$} \\
\hline $\operatorname{Tg}(\mathrm{pT} 2-L a m p 1-m C h e r r y)$ & Ubiquitous & [45] \\
\hline $\operatorname{Tg}(\mathrm{T} \alpha \mathrm{CP}: m$ Cherry-GFP-Map1lc3b) & Cone photoreceptors & [97] \\
\hline $\operatorname{Tg}(\mathrm{T} \alpha \mathrm{CP}: \mathrm{GFP}-\mathrm{Map} 1 \mathrm{lc} 3 \mathrm{~b})$ & Cone photoreceptors & [97] \\
\hline $\operatorname{Tg}(\mathrm{T} \alpha \mathrm{CP}: Y F P-2 X F Y V E)$ & Cone photoreceptors & [97] \\
\hline Tg(CMV:EGFP-Map1lc3b; CMV:mCherry-Map1lc3b) & Ubiquitous & [46] \\
\hline $\mathrm{Tg}(\mathrm{CMV}$ :EGFP-Gabarapa; CMV:mCherry-Map1lc3b) & Ubiquitous & [46] \\
\hline $\operatorname{Tg}($ fabp10: EGFP-Map1lc3b) & Liver & [95] \\
\hline $\operatorname{Tg}(\mathrm{T} \alpha \mathrm{CP}: \mathrm{GFP}-\mathrm{Map} 1 \mathrm{lc} 3 \mathrm{~b})$ & Cone photoreceptors & {$[90]$} \\
\hline pEGFP-Map1lc3b & Transient (embryonic cells) & [103] \\
\hline mCherry-Lc3 mRNA & Transient & {$[104,105]$} \\
\hline pDest(CMV:RFP.GFP.Lc3) mRNA & Transient & [105] \\
\hline GFP-Lc3-RFP-Lc3 $\Delta G$ mRNA & Transient & [101] \\
\hline mCherry-Map1lc3b & Transient & [106] \\
\hline hsp701:RFP-Map1lc3b & Transient & {$[61]$} \\
\hline
\end{tabular}

In cases where there are no stable reporter lines available and one wants to investigate autophagy during embryonic development (up to $5 \mathrm{dpf}$ or depending upon the half-life of the transcribed mRNA), it is possible to inject in vitro transcribed mRNA for a reporter tagged to Lc3 or any other autophagy marker protein, such as mCherry-Lc3 mRNA in vitro transcribed from the vector pDest(CMV:RFP-GFP-Lc3) [104-106].

\subsection{Western Blotting}

The most widely used method for analyzing autophagy is by measuring the levels of lipidated or membrane bound form of Atg8/Lc3B (Atg8-PE/Lc3B-II), as it runs at a different molecular weight than the cytosolic form of Lc3 (Lc3-I) by SDS-PAGE [79,107]. This method has been used to measure levels of autophagy in some zebrafish autophagy studies [46,58,86,95,104,106,108,109]. Again, it cannot be concluded that a mere increase in Lc3-II levels corresponds to increased autophagy, as this can also be due to autolysosomal formation defects, and it is therefore important to do proper autophagic flux experiments (as described above) to conclude about increased/reduced autophagy.

It is very critical to differentiate between the lipidated Lc3-II and the unlipidated Lc3-I when immunoblotting for Lc3. As these two bands lie pretty close to each other (approximately 14 and 16 $\mathrm{kDa}$ ), one can be masked by the other and this problem is intensified if the zebrafish embryo is not deyolked prior to preparing the lysate. The yolk sac is enriched with the protein Vitellogenin and this can cause overloading effects while blotting, if not removed by a deyolking buffer such as Ringer's solution [110]. It is also critical to use gels that give a good separation in the $15 \mathrm{kDa}$ area.

Reproduction of Lc3 blots can be a major hindrance, primarily attributed to changes in experimental setups. The lysis buffer used, the incubation times for blocking, and the primary and secondary antibodies as well as washing periods should be optimized. The type of membrane used for blotting also makes a difference, as Lc3-II binds more effectively to the polyvinylidene fluoride (PVDF) membrane whereas nitrocellulose has a higher affinity for Lc3-I. It is also beneficial to dry the membrane for a short time after transfer to potentially stabilize the binding of Lc3 to the membranes. The following should also be taken into consideration while blotting for Lc3: sensitivity issues of Lc3-I to freeze-thawing (lysates should be run right after boiling), and comparison of Lc3-II levels to a housekeeping protein (e.g., actin or tubulin) rather than comparing them to Lc3-I, as Lc3-I levels can vary (e.g., upon cellular stress and from tissue to tissue) and not necessarily represent autophagy levels. Finally, it is necessary to also monitor the $l c 3 B$ mRNA levels and to compare the correlation between protein Lc3B and mRNA lc3B [79]. 
Even though Lc3 remains the primary target to reveal levels of autophagy, other core autophagy proteins have also been studied. Knockdown of Atg5, Atg7 and Beclin1 in zebrafish were validated via Western blotting in a study aimed at investigating a possible role of autophagy during zebrafish embryogenesis [58]. Beclin1 levels were also examined in ambra-1 knockdown embryos [62]. A detailed list of autophagy related antibodies successfully used for Western blotting and immunofluorescence in zebrafish is shown in Table 3.

Table 3. List of antibodies ever used to detect autophagy-related proteins in zebrafish. (Catalogue numbers listed in italics have been used for immunostaining too).

\begin{tabular}{|c|c|c|c|}
\hline Antibody & Company & Catalogue No. & Reference \\
\hline \multirow{12}{*}{$\mathrm{L}_{\mathrm{C}} 3$} & Novus biologicals & NB100-2220 & {$[93,108,111-116]$} \\
\hline & Novus biologicals & NB100-2331 & {$[86,94,117]$} \\
\hline & Proteintech & 12135-1-AP & [118] \\
\hline & & 4108 & {$[45,109]$} \\
\hline & Cell Signaling & Not indicated & {$[74,104]$} \\
\hline & & 2775 & {$[62,114]$} \\
\hline & & Not indicated & [119] \\
\hline & MBL & PD014 & [95] \\
\hline & & PM036 & [115] \\
\hline & Sigma & L7543 & [59] \\
\hline & Abcam & $a b 51520$ & [106] \\
\hline & Thermo Scientific & PA1-46286 & {$[68]$} \\
\hline Gabarap & Non-commercial & & [86] \\
\hline \multirow{6}{*}{ SQSTM1/p62 } & Abnova & H00008878-M01 & [111] \\
\hline & Cell Signaling & 5114 & {$[94,112]$} \\
\hline & & ab109012 & [117] \\
\hline & Abcam & $a b 31545$ & [68] \\
\hline & MBL Japan & Not indicated & {$[119,120]$} \\
\hline & Cliniscience & PM045 & [67] \\
\hline mTOR & Cell Signalling & 2983 & {$[116]$} \\
\hline Phospho-mTOR, Ser2448 & Cell Signaling & 2971 & [121] \\
\hline Akt & Cell Signaling & Not indicated & [74] \\
\hline Phospho-Akt, Ser473 & Cell Signaling & 9271 & {$[74,121]$} \\
\hline Phospho-S6K, Thr389 & Cell Signaling & 9205 & [121] \\
\hline Phospho-S6K & Cell Signaling & Not indicated & [104] \\
\hline S6k & Cell Signaling & 2708 & [121] \\
\hline \multirow{3}{*}{ Beclin1 } & R\&D systems & Not indicated & [120] \\
\hline & Abcam & Not indicated & {$[104]$} \\
\hline & Santa Cruz & H-300 11427 & {$[58,62]$} \\
\hline Lamp-2A & Abcam & ab18528 & [121] \\
\hline \multirow{4}{*}{ Atg5 } & Novus biologicals & NB110-53818 & {$[59,93]$} \\
\hline & & Not indicated & [108] \\
\hline & Abcam & ab540333 & [59] \\
\hline & Abgent & AP1812a, AP1812b & [59] \\
\hline Actin (loading control) & Sigma & Not indicated & [108] \\
\hline$\alpha$-Tubulin (loading control) & Sigma & T5168 & [73] \\
\hline GAPDH (loading control) & Millipore & Not indicated & [108] \\
\hline
\end{tabular}

\subsection{Transmission Electron Microscopy (TEM)}

Autophagy was first discovered in the 1950s using transmission electron microscopy (TEM) [122]. TEM is a classical and widely used method to observe autophagic structures. If properly sampled, TEM 
provides superlative ultrastructural images with much higher resolution than any light microscope or super-resolution microscope. It gives details of cellular coats, cellular components and bodies in their natural environment $[79,123]$.

TEM has been used to a limited extent in zebrafish autophagy research, owing to the difficulty in sampling and instrument availability. TEM has been used to demonstrate the presence of autophagosomes during zebrafish embryogenesis [58], during caudal fin [91] and muscle regeneration [94] and a variety of other contexts. For example, TEM revealed an increased number of autophagosomes and autolysosomes in the intestinal epithelial cells of zebrafish harboring a mutation in a ribosomal RNA processing gene, $p w p 2 h$ [106]. Here increased autophagy enhanced survival of this zebrafish ribosomopathy model In contrast, aberrant autophagy was observed in a zebrafish motor dysfunction model [71], in Atrogin1-deficient zebrafish [117] and in a variety of zebrafish bacterial infection models $[67,68,92]$. The Salmonella plasmid virulence gene, spvB, was shown to enhance bacterial virulence by inhibiting autophagy [120].

\section{Chemical/Pharmacological Modulations}

Zebrafish embryos are easily treatable by waterborne exposure. Drugs that can modulate autophagic activity by either inducing it, decreasing it or blocking autophagosome-lysosome fusion have been well-used in zebrafish [124]. A detailed list of reagents used to interfere with autophagic activity in zebrafish (until 2014) has been reviewed previously [124]. We here present a list of autophagic modulators used in papers published after 2014 (Table 4, Figure 4).

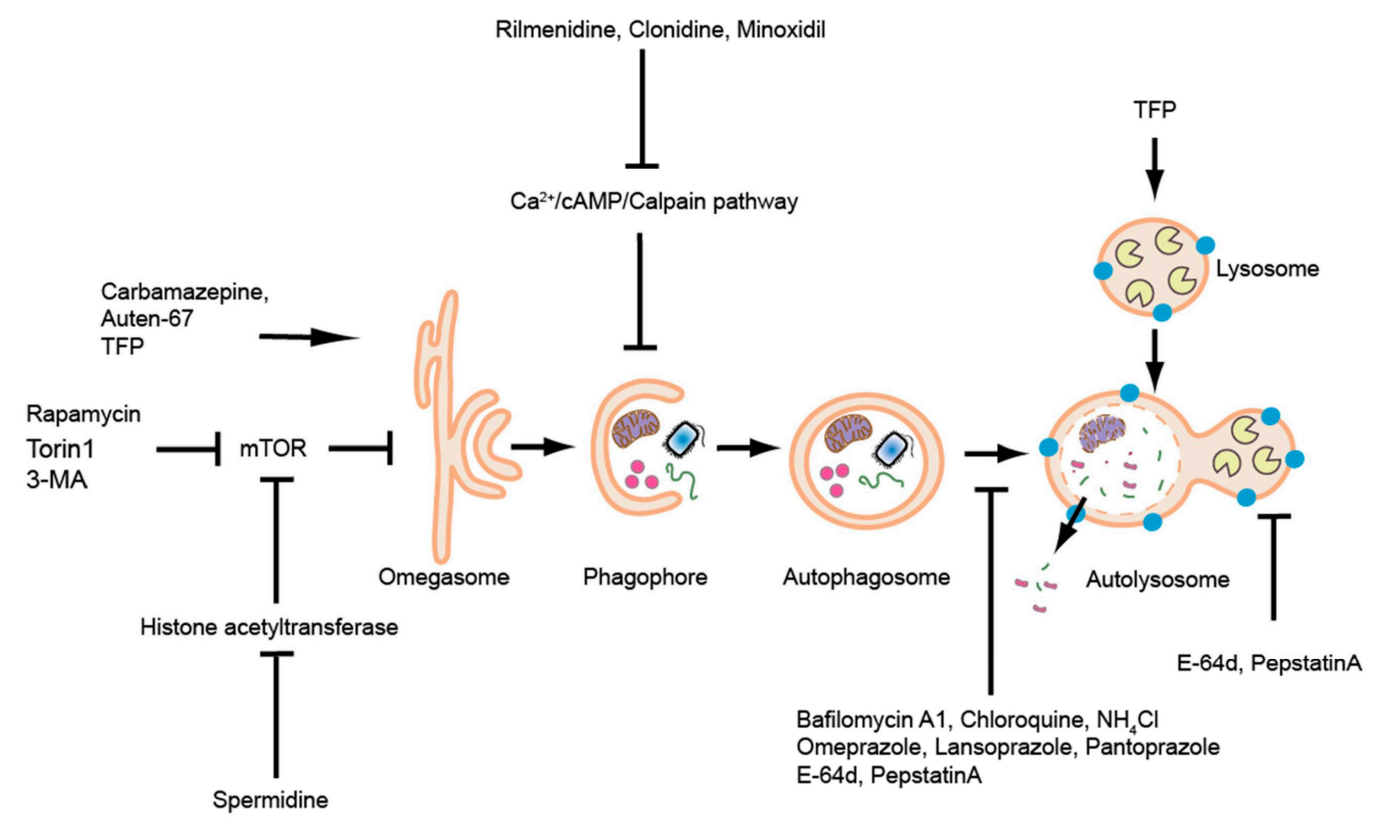

Figure 4. Schematic overview of the autophagic pathway and a partial list of reagents (reagents used beyond 2014, Table 2) that modulate autophagy in zebrafish are indicated. 
Table 4. List of reagents used to modulate autophagic activity in zebrafish (post-2014).

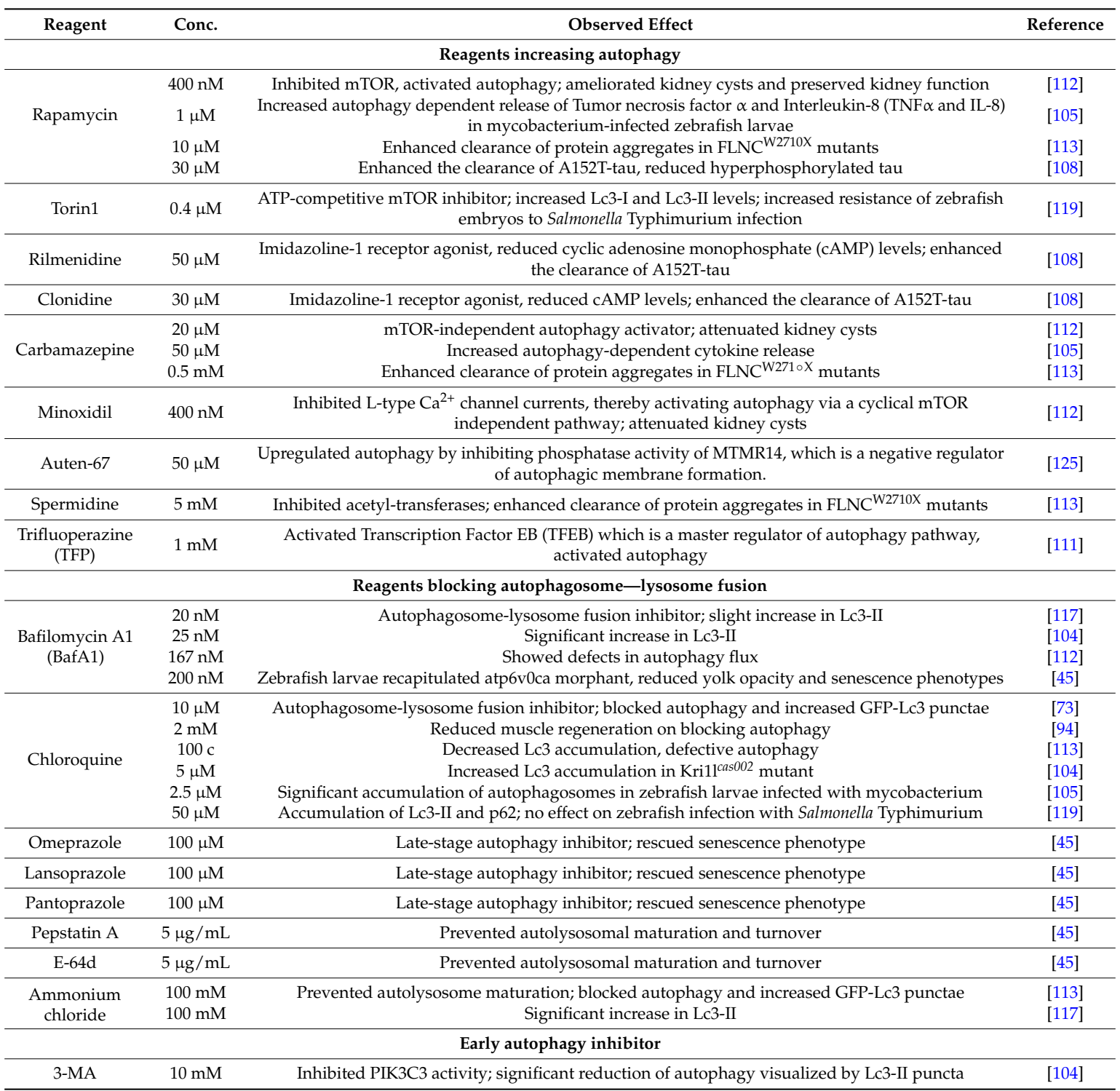

\section{Selective Autophagy}

While induction of autophagy upon nutrient deprivation or other forms of stress is believed to be an unselective process when it comes to the types of cargo being sequestered and degraded to supply cells with essential building-blocks to survive the period of stress until cellular homeostasis is restored. Autophagy can however also be a highly selective process, with different cargo-specific sub-types, including lipophagy (autophagy of lipid droplets), ferrintinophagy (autophagy of iron bound ferritin), lysophagy (autophagy of lysosomes), reticulophagy (autophagy of ER), ribophagy (autophagy of ribosomes), xenophagy (autophagy of pathogens), aggrephagy (autophagy of protein aggregates) and mitophagy (autophagy of damaged mitochondria). Specific cargo binding proteins that also interact with Lc3/GABARAP proteins (so-called autophagy receptors) have been identified and found to facilitate selective autophagy by connecting cargo to the autophagy membrane. Selective autophagy plays an important house-keeping function under basal nutrient-rich conditions to mediate the removal of superfluous or damaged organelles and protein aggregates that otherwise could be toxic. Zebrafish has been used to study degradation of mitochondria and protein aggregates in different neurodegenerative disorder models and to investigate the role of autophagy in protection against 
pathogens, as reviewed below. For most other types of selective autophagy zebrafish have either been not used at all or very scarcely used.

\subsection{Mitophagy}

Selective removal of mitochondria is termed as mitophagy. The degradation of mitochondria by autophagy was already reported in the late 1950s when Clark and Novikoff observed mitochondria within membrane-bound compartments called "dense-bodies", which were later shown to contain lysosomal enzymes $[126,127]$. The term mitophagy was coined by Lemasters and colleagues when they observed the engulfment of mitochondria into vesicular structures coated with Lc3 [128]. Mitophagy is also seen in yeast and this has helped dissect the molecular machinery required for the process $[129,130]$. Some of the proteins required for yeast mitophagy do not have a mammalian orthologue (e.g., Atg32, Atg11), but have functional homologues, e.g., the outer mitochondrial membrane protein NIX acts both like Atg32 and Atg11 [131]. Mitophagy has also been found to be important during key developmental processes, such as the maturation of reticulocytes, after which the matured red blood cells lack mitochondria $[132,133]$.

The E3 ubiquitin ligase Parkin is a major player in mitophagy [134]. Mitochondrial recruitment of Parkin is mediated by the accumulation of PTEN-induced putative kinase protein 1 (PINK1) on depolarized mitochondria [135-137]. NIX has also been shown to promote Parkin translocation and thereby promote mitophagy in mouse embryonic fibroblasts [138]. Loss of function mutations in the gene encoding Parkin (park2) have been linked to Parkinson's disease (PD) with loss of dopaminergic neurons in the substantia nigra, a region in the mid brain that is responsible for motor function [139]. Parkinsonian syndrome has also been shown in zebrafish morphants lacking pink1 [140] and park2 [141], with dopaminergic cell loss. A TILLING (targeting-induced local lesions in genomes) mutant for pink1 also shows significant reduction in the number of tyrosine hydroxylase $(\mathrm{TH})^{+}$cells and a reduction in mitochondrial complex I activity [142]. Thus, mitophagy dysfunction or an inability to degrade damaged mitochondria leading to accumulation of mitochondrial damage is a likely cause of PD.

Proteins involved in mammalian mitophagy are well conserved in zebrafish [143], which makes zebrafish a good model to further delineate the functional significance of mitophagy in vivo. There have not yet been many mitophagy studies in zebrafish, but several tools exist to study mitochondrial dynamics. One study tried to observe sites for mitophagy in Rohon Beard neurons of zebrafish where UAS:LC3.GFP was coinjected with UAS:mitoTagRFP-T into the Isl2b:Gal4 transgenic line. Lc3 was found to colocalize with mitochondria, but proper mitophagy assays were not performed [144]. It would be highly interesting to see if Lc3 disappeared over time from these contact points. As mentioned earlier, a tandem-based approach to tagging mitochondrial proteins would help in observing their degradation kinetics via autophagy. It is a highly exciting time for zebrafish mitophagy studies. One major problem is however the lack of antibodies for zebrafish mitochondrial proteins, but with larger research interest churning up for mitochondrial studies, this scenario is likely to diminish fast.

\subsection{Aggrephagy}

Several neurodegenerative disorders and prion diseases are characterized by neuronal protein aggregates and inclusion body formation. Aggregates are formed due the accumulation of misfolded proteins [145]. Misfolded proteins can either be degraded by the ubiquitin-proteasome system (UPS), through chaperone-mediated autophagy (CMA) or by macroautophagy. Almost all soluble proteins (except for the long lived proteins) are turned over by the UPS, but as large protein-aggregates are difficult to degrade by the UPS, they are degraded by autophagy [146].

The zebrafish is a well-known model for the study of neurodegenerative disorders. Pharmacological modulation of autophagy in such zebrafish models of neurodegeneration has shown promising results. The first study to mention autophagy in zebrafish used a zebrafish Huntington's disease (HD) model expressing EGFP-HDQ71 aggregates, where autophagy was found to be upregulated by reagents such as calpastatin, calpeptin, $2^{\prime} 5^{\prime} \mathrm{DDA}$ and clonidine (Table 2 ), resulting 
in a decrease in EGFP-HDQ71 aggregates [147]. HD is caused by glutamine expansions (polyQ) in the gene encoding the Huntingtin protein that make it prone to misfold and aggregate. In another study using the zebrafish HD model expressing EGFP-HDQ71 it was demonstrated that autophagy inducers like rapamycin and clonidine cleared the aggregate in the retina [148]. A zebrafish model of Alzheimer's disease (AD) is characterized by neuronal tau aggregates and was found to have reduced aggregate clearance and decreased Lc3-II levels upon overexpression of phosphatidylinositol binding clathrin assembly protein (Picalm) [114]. PICALMs are known to interact with and thereby regulate the endocytosis of Soluble NSF Attachment Protein Receptor proteins (SNAREs), such as VAMP2, VAMP3 and VAMP8 [149]. In a recent study, it was seen that clonidine, rilmenidine and rapamycin had positive effects on the clearance of aggregated A152T-tau. It was also observed that transient overexpression of Atg 5 upregulated autophagy in zebrafish larvae by $2 \mathrm{dpf}$, evident by an increase in lipidated Lc3-II and a reduction in hyperphosphorylated tau—one that causes aggregation of tau [108]. BAG3 is a key component of the chaperone-assisted selective autophagy (CASA) pathway [150]. It was recently found that in a transgenic zebrafish model of myofibrillar myopathy (induced by expression of a mutant of filamin C (FLNC ${ }^{\text {W2710X }}$-eGFP)) the BAG3-mediated CASA pathway is impaired and insufficient in clearing the FLNC ${ }^{\mathrm{W} 2710 \mathrm{X}}$ aggregates, and that autophagy promoting compounds like rapamycin or carbamazepine facilitated aggregate reduction [113].

The zebrafish as a model is proving to be essential for understanding disease mechanisms of several neurodegenerative disorders characterized by insoluble protein aggregates. There are a plethora of studies showing reduction of protein aggregates by the induction of autophagy. So far, molecular studies on the sequestration of aggregates into autophagosomes have not elucidated the role of different autophagy proteins during aggrephagy in zebrafish. This is very likely to change in the near future with the advent of CRISPR/Cas9 technology and the availability of antibodies for protein studies. The transparency of the zebrafish and its amenability to different drugs makes them an excellent model for neurodegenerative research.

\subsection{Xenophagy}

The role of autophagy as an anti-microbial mechanism was first demonstrated in studies by Yoshimori and co-workers, who showed that Streptococcus pyogenes multiplied in Atg5-deficient cells and by Deretic and co-workers, who showed that intracellular survival of Mycobacterium tuberculosis could be limited by starvation-induced or rapamycin-induced autophagy [151,152]. Since then autophagy has become recognized as a crucial defense mechanism against bacterial, viral, fungal, and protozoan pathogens [14]. Once internalized by host cells, microbial invaders often escape from phagosomes into the cytosol, where they become targets for xenophagy. Cytoplasmic microbes or damaged membranes of phagosomes are marked by molecular tags such as ubiquitin and galectins, which are the substrates for recognition by selective autophagy receptors that are also involved in mitophagy [153]. The autophagy receptors p62 and optineurin have been shown to protect against bacterial infections in zebrafish models [66,67]. Autophagy-related mechanisms distinct from xenophagy also play a role in host defense. In particular, Lc3 can be recruited directly to phagosomes in a process named Lc3-associated phagocytosis (LAP) [154]. Pathogens have evolved various strategies to evade xenophagy or LAP $[155,156]$. Zebrafish models for Salmonella typhimurium and Mycobacterium marinum infection have been used to study some of the virulence mechanisms that pathogens use to counteract the host autophagy response [119,120,157]. In addition, it has been shown that pharmacological stimulation of autophagy can improve the zebrafish host defense against Mycobacterium marinum infection [105,118].

GFP-Lc3 transgenic zebrafish have been used to study bacterial infections with Shigella flexneri and M. marinum $[67,77,102,158]$. Both these pathogens have the ability to escape from phagosomes and replicate inside the cytosol. A proportion of cytosolic Shigella bacteria are trapped inside cage-like structures formed by septins, which are cytoskeletal components that prevent Shigella from actin tail formation and cell-to-cell spreading [159]. In vitro studies have shown that septin-caged 
Shigella are targeted to autophagy [159]. In agreement, in vivo imaging of zebrafish embryos demonstrated recruitment of GFP-Lc3 and the presence of bacteria in autophagosomes was confirmed by ultrastructural analysis [67]. Septin-caged M. marinum bacteria were also observed in zebrafish embryos, but the significance of septin caging in relation to autophagic targeting remains to be investigated [67]. Entrapment of M. marinum bacteria by GFP-Lc3 vesicles could be visualized by confocal time lapse imaging of infected zebrafish [92]. This study also revealed that GFP-Lc3 vesicles frequently appeared as puncta in close vicinity of single bacteria or bacterial clusters (Figure 5). Correlative light and electron microscopy confirmed that these vesicles represent autophagosomes, which might contribute to the delivery of ubiquitinated antimicrobial peptides to the M. marinum -containing compartments [92,160].

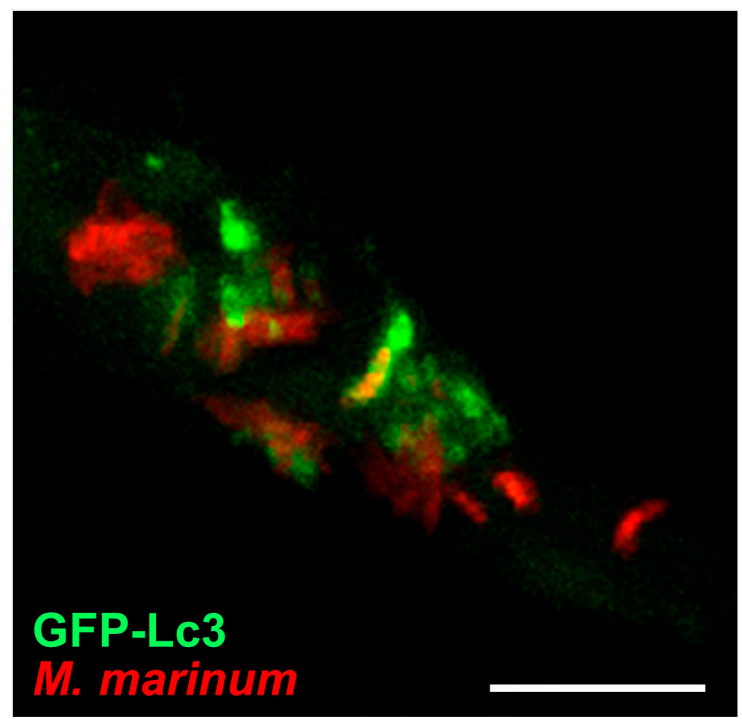

Figure 5. Confocal imaging of Tg(CMV:EGFP-Mapllc3b) on infection. GFP-Lc3 signal around clusters of M. marinum bacteria in 4-day-old zebrafish larva at 3 days post infection. Scale bars, $10 \mu \mathrm{M}$.

Dram1 is an autophagy modulator that is induced during infection of zebrafish by the MYD88-NFkB-dependent signaling pathway, which occurs downstream of pathogen recognition by Toll-like receptors [68]. Expression of zebrafish Dram1 can also be induced by the p53-stabilizing agent roscovitin, in agreement with the identification of human DRAM1 as a p53 target gene [68,161]. Overexpression of Dram1 by mRNA injection was found to result in increased lysosomal acidification of $M$. marinum containing compartments and to improve resistance of zebrafish embryos to the infection [68]. In addition, Dram1 overexpression enhances GFP-Lc3 recruitment to M. marinum and this function requires the cytosolic DNA sensor Sting and the ubiquitin receptor p62. In agreement, morpholino knockdown of Dram1 reduced GFP-Lc3 recruitment to M. marinum and impaired host defense [68]. Dram1 is a member of a conserved family of transmembrane proteins and localizes predominantly to lysosomes [161]. Its precise mechanism of action is currently unknown, but a recent study on a human family member, DRAM2, suggests an interaction with the Beclin1-Vps34-UVRAG complex, which leads to displacement of the inhibitor Rubicon and thereby enhanced PI3K activity [162]. Since M. marinum infection in zebrafish mimics aspects of human tuberculosis, further research into the Dram1-mediated selective autophagy pathway could help to develop novel strategies for host-directed anti-tuberculosis therapy [160].

Recently, the zebrafish has also been used to study the host autophagic response to a viral infection [109]. Zebrafish can be infected with spring viremia of carp virus (SVCV), a member of the rhabdovirus family. Infection with this virus induces the production of $\operatorname{Tnf} \alpha$, a potent pro-inflammatory cytokine that normally serves a host-protective function, but is exploited by certain viruses to their 
benefit. GFP-Lc3 imaging and Western blot analysis showed that depletion of Tnf $\alpha$ increased autophagy in SVCV-infected larvae. Since depletion of $\operatorname{Tnf} \alpha$ also improved resistance to SVCV infection, the authors concluded that inhibition of autophagy is the mechanism behind the deleterious effect of $\operatorname{Tnf} \alpha$ on viral clearance [109]. A wide variety of other zebrafish infection models provide excellent tools to further advance our understanding of the role of autophagy in host-pathogen interactions [163].

\section{Future Perspective}

The zebrafish is fast becoming one of the best vertebrate models for studying disease states and conditions. Owing to the various advantages that they pose and the ease at which the present advancements in genome editing technology can be applied, zebrafish hold unparalleled potential for all basic and translational research. Existing studies of autophagy in zebrafish have presented invaluable insight into the role of autophagy in development, disease progression and drug discovery. There is still however a need for antibodies that recognize specific zebrafish autophagy proteins, and their modifications (at present a limitation). The contribution of CRISPR/Cas9 to scientific research has been immense, but the overall technology depends upon efficient sgRNAs and thus having a database system to maintain and expand the existing sgRNAs is a must. Autophagy research has been expanding and the vitality of autophagy as a degradation system has been acknowledged worldwide with Yoshinori Ohsumi receiving the Nobel Prize in Medicine or Physiology in 2016. Autophagy research using the zebrafish as a model system looks promising for many more breakthroughs and new therapeutics against many diseases.

Acknowledgments: Work that led to this review has been supported by the Research Council of Norway (project 221831), the Netherlands Technology Foundation STW (project 13259), the Smartmix program of the Netherlands Ministry of Economic Affairs and the Ministry of Education, Culture and Science (project NWOA_6QY9BM), the Horizon 2020 COST action TRANSAUTOPHAGY (CA15138) and the Norwegian Centennial Chair Program. We would like to thank Philippe Collas, Håvard Aanes and Peter Aleström for sharing RNA-seq data and Carina Knudsen for helping us with the figures.

Author Contributions: All authors contributed to writing of the manuscript.

Conflicts of Interest: The authors have no conflicts of interest.

\section{References}

1. Boya, P.; Reggiori, F.; Codogno, P. Emerging regulation and functions of autophagy. Nat. Cell Biol. 2013, 15, 713-720. [CrossRef] [PubMed]

2. Takeshige, K.; Baba, M.; Tsuboi, S.; Noda, T.; Ohsumi, Y. Autophagy in Yeast Demonstrated with Proteinase-deficient Mutants and Conditions for its Induction. J. Cell Biol. 1992, 119, 301-311. [CrossRef] [PubMed]

3. Tsukada, M.; Ohsumi, Y. Isofation and charactization of autophagy-defective mutants of Saccharomyces cerevisiae. FEBS Lett. 1993, 333, 169-174. [CrossRef]

4. Thumm, M.; Egner, R.; Koch, B.; Schlumpberger, M.; Straub, M.; Veenhuis, M.; Wolf, D.H. Isolation of autophagocytosis mutants of Saccharomyces cerevisiae. FEBS Lett. 1994, 349, 275-280. [CrossRef]

5. Harding, T.M.; Morano, K.A.; Scott, S.V.; Klionsky, D.J. Isolation and characterization of yeast mutants in the cytoplasm to vacuole protein targeting pathway. J. Cell Biol. 1995, 131, 591-602. [CrossRef] [PubMed]

6. Yang, Z.; Klionsky, D.J. An Overview of the Molecular Mechanism. Curr. Top. Microbiol. Immunol. 2009, 3112-3123. [CrossRef]

7. Xie, Z.; Klionsky, D.J. Autophagosome formation: core machinery and adaptations. Nat. Cell Biol. 2007, 9, 1102-1109. [CrossRef] [PubMed]

8. He, C.; Klionsky, D.J. Regulation Mechanisms and Signalling Pathways of Autophagy. Annu. Rev. Genet. 2009, 43, 67. [CrossRef] [PubMed]

9. Mizushima, N.; Yoshimori, T.; Ohsumi, Y. The Role of Atg Proteins in Autophagosome Formation. Annu. Rev. Cell Dev. Biol. 2011, 27, 107-132. [CrossRef] [PubMed] 
10. Katheder, N.S.; Khezri, R.; O’Farrell, F.; Schultz, S.W.; Jain, A.; Rahman, M.M.; Schink, K.O.; Theodossiou, T.A.; Johansen, T.; Juhász, G.; et al. Microenvironmental autophagy promotes tumour growth. Nature 2017, 541, 417-420. [CrossRef] [PubMed]

11. Chen, N. Jayanta Debnath Autophagy and tumorigenesis. FEBS Lett. 2009, 32, 383-396. [CrossRef]

12. Shibutani, S.T.; Saitoh, T.; Nowag, H.; Munz, C.; Yoshimori, T. Autophagy and autophagy-related proteins in the immune system. Nat Immunol 2015, 16, 1014-1024. [CrossRef] [PubMed]

13. Plaza-Zabala, A.; Sierra-Torre, V.; Sierra, A. Autophagy and Microglia: Novel Partners in Neurodegeneration and Aging. Int. J. Mol. Sci. 2017, 18, 598. [CrossRef] [PubMed]

14. Deretic, V.; Saitoh, T.; Akira, S. Autophagy in infection, inflammation and immunity. Nat. Rev. Immunol. 2013, 13, 722-737. [CrossRef] [PubMed]

15. Saxton, R.A.; Sabatini, D.M. mTOR Signaling in Growth Control and Disease. Cell 2017, 149, $274-293$. [CrossRef]

16. Rearick Shoup, J. the Development Eyes of Pigment Type and Granules in the Eyes of Wild Type and Mutant Drosophila Melanogaster. J. Cell Biol. 1966, 29, 223-249. [CrossRef]

17. Juhász, G.; Csikós, G.; Sinka, R.; Erdélyi, M.; Sass, M. The Drosophila homolog of Aut1 is essential for autophagy and development. FEBS Lett. 2003, 543, 154-158. [CrossRef]

18. Meléndez, A.; Tallóczy, Z.; Seaman, M.; Eskelinen, E.-L.; Hall, D.H.; Levine, B. Autophagy genes are essential for dauer development and life-span extension in C. elegans. Science 2003, 301, 1387-1391. [CrossRef] [PubMed]

19. Mizushima, N.; Kuma, A.; Kobayashi, Y.; Yamamoto, A.; Matsubae, M.; Takao, T.; Natsume, T.; Ohsumi, Y.; Yoshimori, T. Mouse Apg16L, a novel WD-repeat protein, targets to the autophagic isolation membrane with the Apg12-Apg5 conjugate. J Cell Sci 2003, 116, 1679-1688. [CrossRef] [PubMed]

20. Mizushima, N.; Yamamoto, A.; Hatano, M.; Kobayashi, Y.; Kabey, Y.; Suzuki, K.; Tokuhis, T.; Ohsumi, Y.; Yoshimori, T. Dissection of autophagosome formation using Apg5-deficient mouse embryonic stem cells. J. Cell Biol. 2001, 152, 657-667. [CrossRef] [PubMed]

21. Moreau, P.; Moreau, K.; Segarra, A.; Tourbiez, D.; Travers, M.; Rubinsztein, D.C.; Renault, T. Autophagy plays an important role in protecting Pacific oysters from OsHV-1 and Vibrio aestuarianus infections. Autophagy 2015, 11, 516-526. [CrossRef] [PubMed]

22. Calvo-Garrido, J.; Carilla-Latorre, S.; Kubohara, Y.; Santos-Rodrigo, N.; Mesquita, A.; Soldati, T.; Golstein, P.; Escalante, R. Autophagy in dictyostelium: Genes and pathways, cell death and infection. Autophagy 2010, 6, 686-701. [CrossRef] [PubMed]

23. Basu, S.; Sachidanandan, C. Zebrafish: A multifaceted tool for chemical biologists. Chem. Rev. 2013, 113, 7952-7980. [CrossRef] [PubMed]

24. Driever, W.; Solnica-Krezel, L.; Schier, A.F.; Neuhauss, S.C.; Malicki, J.; Stemple, D.L.; Stainier, D.Y.; Zwartkruis, F.; Abdelilah, S.; Rangini, Z.; et al. A genetic screen for mutations affecting embryogenesis in zebrafish. Development 1996, 123, 37-46. [PubMed]

25. Howe, K.; Clark, M.D.; Torroja, C.F.; Torrance, J.; Berthelot, C.; Muffato, M.; Collins, J.E.; Humphray, S.; McLaren, K.; Matthews, L.; et al. The zebrafish reference genome sequence and its relationship to the human genome. Nature 2013, 496, 498-503. [CrossRef] [PubMed]

26. Kettleborough, R.N.; Busch-Nentwich, E.M.; Harvey, S.A.; Dooley, C.M.; de Bruijn, E.; van Eeden, F.; Sealy, I.; White, R.J.; Herd, C.; Nijman, I.J.; et al. A systematic genome-wide analysis of zebrafish protein-coding gene function. Nature 2013, 496, 494-497. [CrossRef] [PubMed]

27. Schier, A.F. Zebrafish earns its stripes. Nature 2013, 496, 443-444. [CrossRef]

28. Jinek, M.; Chylinski, K.; Fonfara, I.; Hauer, M.; Doudna, J.A.; Charpentier, E. A Programmable Dual-RNA Guided. Science 2012, 337, 816-822. [CrossRef] [PubMed]

29. Garneau, J.E.; Dupuis, M.E.; Villion, M.; Romero, D.A.; Barrangou, R.; Boyaval, P.; Fremaux, C.; Horvath, P.; Magadan, A.H.; Moineau, S. The CRISPR/Cas bacterial immune system cleaves bacteriophage and plasmid DNA. Nature 2010, 468, 67-71. [CrossRef] [PubMed]

30. Gasiunas, G.; Barrangou, R.; Horvath, P.; Siksnys, V. Cas9-crRNA ribonucleoprotein complex mediates specific DNA cleavage for adaptive immunity in bacteria. Proc. Natl. Acad. Sci. USA 2012, 109, E2579-E2586. [CrossRef] [PubMed]

31. Komor, A.C.; Badran, A.H.; Liu, D.R. CRISPR-Based Technologies for the Manipulation of Eukaryotic Genomes. Cell 2016, 168, 1-17. [CrossRef] 
32. Li, M.; Zhao, L.; Page-McCaw, P.S.; Chen, W. Zebrafish Genome Engineering Using the CRISPR-Cas9 System. Trends Genet. 2016, 32, 815-827. [CrossRef] [PubMed]

33. Varshney, G.K.; Pei, W.; LaFave, M.C.; Idol, J.; Xu, L.; Gallardo, V.; Carrington, B.; Bishop, K.; Jones, M.; Li, M.; et al. High-throughput gene targeting and phenotyping in zebrafish using CRISPR/Cas9. Genome Res. 2015, 25, 1030-1042. [CrossRef] [PubMed]

34. Moreno-Mateos, M.A.; Vejnar, C.E.; Beaudoin, J.; Fernandez, J.P.; Mis, E.K.; Khokha, M.K.; Giraldez, A.J. CRISPRscan: Designing highly efficient sgRNAs for CRISPR-Cas9 targeting in vivo. Nat. Methods 2015, 12, 982-988. [CrossRef] [PubMed]

35. Sung, Y.; Kim, J.; Kim, H.; Lee, J.; Jeon, J. Highly efficient gene knockout in mice and zebrafish with RNA-guided endonucleases. Genome Res. 2014, 24, 125-131. [CrossRef] [PubMed]

36. Huang, P.; Xiao, A.; Zhou, M.; Zhu, Z.; Lin, S.; Zhang, B. Heritable gene targeting in zebrafish using customized TALENs. Nat. Biotechnol. 2011, 29, 699-700. [CrossRef] [PubMed]

37. Doyon, Y.; McCammon, J.M.; Miller, J.C.; Faraji, F.; Ngo, C.; Katibah, G.E.; Amora, R.; Hocking, T.D.; Zhang, L.; Rebar, E.J.; et al. Heritable targeted gene disruption in zebrafish using designed zinc-finger nucleases. Nat. Biotechnol. 2008, 26, 702-708. [CrossRef] [PubMed]

38. Hwang, W.Y.; Fu, Y.; Reyon, D.; Maeder, M.L.; Tsai, S.Q.; Sander, J.D.; Peterson, R.T.; Yeh, J.R.; Joung, J.K. Efficient genome editing in zebrafish using a CRISPR-Cas system. Nat Biotechnol 2013, 31, 227-229. [CrossRef] [PubMed]

39. Hoshijima, K.; Jurynec, M.J.; Grunwald, D.J. Precise Editing of the Zebrafish Genome Made Simple and Efficient. Dev. Cell 2016, 36, 654-667. [CrossRef] [PubMed]

40. Jao, L.-E.; Wente, S.R.; Chen, W. Efficient multiplex biallelic zebrafish genome editing using a CRISPR nuclease system. Proc. Natl. Acad. Sci. USA 2013, 110, 13904-13909. [CrossRef] [PubMed]

41. Yin, L.; Maddison, L.A.; Li, M.; Kara, N.; Lafave, M.C.; Varshney, G.K.; Burgess, S.M.; Patton, J.G.; Chen, W. Multiplex conditional mutagenesis using transgenic expression of Cas9 and sgRNAs. Genetics 2015, 200, 431-441. [CrossRef] [PubMed]

42. Auer, T.O.; Duroure, K.; De Cian, A.; Concordet, J.; Del Bene, F. Highly efficient CRISPR / Cas9-mediated knock-in in zebrafish by homology-independent DNA repair. Genome Res. 2014, 24, 142-153. [CrossRef] [PubMed]

43. Yin, L.; Jao, L.-E.; Chen, W. Generation of Targeted Mutations in Zebrafi sh Using the CRISPR/Cas System. Methods Mol. Biol. 2015, 1332, 7-8. [CrossRef]

44. Gonzales, A.P. W.; Joanna Yeh, J.R. Cas9-based genome editing in Zebrafish. Methods Enzymol. 2014, 546, 377-413. [CrossRef] [PubMed]

45. Sasaki, T.; Lian, S.; Khan, A.; Llop, J.R.; Samuelson, A.V.; Chen, W.; Klionsky, D.J.; Kishi, S. Autolysosome biogenesis and developmental senescence are regulated by both Spns1 and v-ATPase. Autophagy 2016, 13, 1-18. [CrossRef] [PubMed]

46. Sasaki, T.; Lian, S.; Qi, J.; Bayliss, P.E.; Carr, C.E.; Johnson, J.L.; Guha, S.; Kobler, P.; Catz, S.D.; Gill, M.; et al. Aberrant Autolysosomal Regulation Is Linked to The Induction of Embryonic Senescence: Differential Roles of Beclin 1 and p53 in Vertebrate Spns1 Deficiency. PLoS Genet. 2014, 10. [CrossRef] [PubMed]

47. Rong, Y.; McPhee, C.K.; Deng, S.; Huang, L.; Chen, L.; Liu, M.; Tracy, K.; Baehrecke, E.H.; Yu, L.; Lenardo, M.J. Spinster is required for autophagic lysosome reformation and $\mathrm{mTOR}$ reactivation following starvation. Proc. Natl. Acad. Sci. 2011, 108, 7826-7831. [CrossRef] [PubMed]

48. Huang, G.; Zhang, F.; Ye, Q.; Wang, H. The circadian clock regulates autophagy directly through the nuclear hormone receptor $\mathrm{Nr} 1 \mathrm{~d} 1 / \operatorname{Rev}$-erb $\alpha$ and indirectly via $\mathrm{Cebpb} /(\mathrm{C} / \mathrm{ebp} \beta)$ in zebrafish. Autophagy 2016, 12, 1292-1309. [CrossRef] [PubMed]

49. Corey, D.R.; Abrams, J.M. Morpholino antisense oligonucleotides: tools for investigating vertebrate development. Genome Biol. 2001, 2, 1015.1-1015.3. [CrossRef]

50. Bill, B.R.; Petzold, A.M.; Clark, K.J.; Schimmenti, L.A.; Ekker, S.C. A primer for morpholino use in zebrafish. Zebrafish 2009, 6, 69-77. [CrossRef] [PubMed]

51. Khokha, M.K.; Yeh, J.; Grammer, T.C.; Harland, R.M. Depletion of three BMP antagonists from Spemann's organizer leads to a catastrophic loss of dorsal structures. Dev. Cell 2005, 8, 401-411. [CrossRef] [PubMed]

52. Mir, A.; Heasman, J. How The Mother Can Help: Studying Maternal Wnt Signaling by Anti-sense-mediated Depletion of Maternal mRNAs and the Host Transfer Technique. Methods Mol. Biol. 2008, 469, $21-32$. [CrossRef] 
53. Robu, M.E.; Larson, J.D.; Nasevicius, A.; Beiraghi, S.; Brenner, C.; Farber, S.A.; Ekker, S.C. P53 Activation By Knockdown Technologies. PLoS Genet. 2007, 3, 787-801. [CrossRef] [PubMed]

54. Kok, F.O.; Shin, M.; Ni, C.W.; Gupta, A.; Grosse, A.S.; van Impel, A.; Kirchmaier, B.C.; Peterson-Maduro, J.; Kourkoulis, G.; Male, I.; et al. Reverse genetic screening reveals poor correlation between morpholino-induced and mutant phenotypes in zebrafish. Dev. Cell 2015, 32, 97-108. [CrossRef] [PubMed]

55. Rossi, A.; Kontarakis, Z.; Gerri, C.; Nolte, H.; Hölper, S.; Krüger, M.; Stainier, D.Y.R. Genetic compensation induced by deleterious mutations but not gene knockdowns. Nature 2015, 13, 230-233. [CrossRef] [PubMed]

56. Schaefer, K.A.; Wu, W.-H.; Colgan, D.F.; Tsang, S.H.; Bassuk, A.G.; Mahajan, V.B. Unexpected mutations after CRISPR-Cas9 editing in vivo. Nat. Publ. Gr. 2017, 14, 547-548. [CrossRef] [PubMed]

57. Blum, M.; De Robertis, E.M.; Wallingford, J.B.; Niehrs, C. Morpholinos: Antisense and Sensibility. Dev. Cell 2015, 35, 145-149. [CrossRef] [PubMed]

58. Lee, E.; Koo, Y.; Ng, A.; Wei, Y.; Luby-Phelps, K.; Juraszek, A.; Xavier, R.J.; Cleaver, O.; Levine, B.; Amatruda, J.F. Autophagy is essential for cardiac morphogenesis during vertebrate development. Autophagy 2014, 10, 572-587. [CrossRef] [PubMed]

59. Hu, Z.; Zhang, J.; Zhang, Q. Expression pattern and functions of autophagy-related gene atg5 in zebrafish organogenesis. Autophagy 2011, 7, 1514-1527. [CrossRef] [PubMed]

60. Kyöstilä, K.; Syrjä, P.; Jagannathan, V.; Chandrasekar, G.; Jokinen, T.S.; Seppälä, E.H.; Becker, D.; Drögemüller, M.; Dietschi, E.; Drögemüller, C.; et al. A Missense Change in the ATG4D Gene Links Aberrant Autophagy to a Neurodegenerative Vacuolar Storage Disease. PLoS Genet. 2015, 11, 1-22. [CrossRef] [PubMed]

61. Skobo, T.; Benato, F.; Grumati, P.; Meneghetti, G.; Cianfanelli, V.; Castagnaro, S.; Chrisam, M.; Di Bartolomeo, S.; Bonaldo, P.; Cecconi, F.; et al. Zebrafish ambra1a and ambra1b knockdown impairs skeletal muscle development. PLoS ONE 2014, 9. [CrossRef] [PubMed]

62. Benato, F.; Skobo, T.; Gioacchini, G.; Moro, I.; Ciccosanti, F.; Piacentini, M.; Fimia, G.M.; Carnevali, O.; Valle, L.D. Ambra1 knockdown in zebrafish leads to incomplete development due to severe defects in organogenesis. Autophagy 2013, 9, 476-495. [CrossRef] [PubMed]

63. Nakai, A.; Yamaguchi, O.; Takeda, T.; Higuchi, Y.; Hikoso, S.; Taniike, M.; Omiya, S.; Mizote, I.; Matsumura, Y.; Asahi, M.; et al. The role of autophagy in cardiomyocytes in the basal state and in response to hemodynamic stress. Nat. Med. 2007, 13, 619-624. [CrossRef] [PubMed]

64. Korac, J.; Schaeffer, V.; Kovacevic, I.; Clement, A.M.; Jungblut, B.; Behl, C.; Terzic, J.; Dikic, I. Ubiquitin-independent function of optineurin in autophagic clearance of protein aggregates. J. Cell Sci. 2013, 126, 580-592. [CrossRef] [PubMed]

65. Paulus, J.D.; Link, B.A. Loss of Optineurin in vivo results in elevated cell death and alters axonal trafficking dynamics. PLoS ONE 2014, 9. [CrossRef] [PubMed]

66. Chew, T.S.; O'Shea, N.R.; Sewell, G.W.; Oehlers, S.H.; Mulvey, C.M.; Crosier, P.S.; Godovac-Zimmermann, J.; Bloom, S.L.; Smith, A.M.; Segal, A.W. Optineurin deficiency contributes to impaired cytokine secretion and neutrophil recruitment in bacteria driven colitis. Dis. Model. Mech. 2015, 6, 817-829. [CrossRef] [PubMed]

67. Mostowy, S.; Boucontet, L.; Mazon Moya, M.J.; Sirianni, A.; Boudinot, P.; Hollinshead, M.; Cossart, P.; Herbomel, P.; Levraud, J.P.; Colucci-Guyon, E. The Zebrafish as a New Model for the In Vivo Study of Shigella flexneri Interaction with Phagocytes and Bacterial Autophagy. PLoS Pathog. 2013, 9, 12-16. [CrossRef] [PubMed]

68. Van Der Vaart, M.; Korbee, C.J.; Lamers, G.E. M.; Tengeler, A.C.; Hosseini, R.; Haks, M.C.; Ottenhoff, T.H. M.; Spaink, H.P.; Meijer, A.H. The DNA damage-regulated autophagy modulator DRAM1 links mycobacterial recognition via TLP-MYD88 to authophagic defense. Cell Host Microbe 2014, 15, 753-767. [CrossRef] [PubMed]

69. Lattante, S.; De Calbiac, H.; Le Ber, I.; Brice, A.; Ciura, S.; Kabashi, E. Sqstm1 knock-down causes a locomotor phenotype ameliorated by rapamycin in a zebrafish model of ALS/FTLD. Hum. Mol. Genet. 2015, 24, 1682-1690. [CrossRef] [PubMed]

70. Akizu, N.; Cantagrel, V.; Zaki, M.S.; Al-Gazali, L.; Wang, X.; Rosti, R.O.; Dikoglu, E.; Gelot, A.B.; Rosti, B.; Vaux, K.K.; et al. Biallelic mutations in SNX14 cause a syndromic form of cerebellar atrophy and lysosome-autophagosome dysfunction. Nat. Genet. 2015, 47, 528-534. [CrossRef] [PubMed] 
71. Dowling, J.J.; Low, S.E.; Busta, A.S.; Feldman, E.L. Zebrafish MTMR14 is required for excitation-contraction coupling, developmental motor function and the regulation of autophagy. Hum. Mol. Genet. 2010, 19, 2668-2681. [CrossRef] [PubMed]

72. Vergne, I.; Roberts, E.; Elmaoued, R.A.; Tosch, V.; Delgado, M.A.; Proikas-Cezanne, T.; Laporte, J.; Deretic, V. Control of autophagy initiation by phosphoinositide 3-phosphatase Jumpy. EMBO J. 2009, 28, 2244-2258. [CrossRef] [PubMed]

73. Holland, P.; Knævelsrud, H.; Søreng, K.; Mathai, B.J.; Lystad, A.H.; Pankiv, S.; Bjørndal, G.T.; Schultz, S.W.; Lobert, V.H.; Chan, R.B.; et al. HS1BP3 negatively regulates autophagy by modulation of phosphatidic acid levels. Nat. Commun. 2016, 7, 13889. [CrossRef] [PubMed]

74. Ramanoudjame, L.; Rocancourt, C.; Laine, J.; Klein, A.; Joassard, L.; Gartioux, C.; Fleury, M.; Lyphout, L.; Kabashi, E.; Ciura, S.; et al. Two novel COLVI long chains in zebrafish that are essential for muscle development. Hum. Mol. Genet. 2015, 24, 6624-6639. [CrossRef] [PubMed]

75. Payne, E.M.; Virgilio, M.; Narla, A.; Sun, H.; Levine, M.; Paw, B.H.; Berliner, N.; Look, A.T.; Ebert, B.L.; Khanna-Gupta, A. L-leucine improves the anemia and developmental defects associated with Diamond-Blackfan anemia and del(5q)MDSby activating themTORpathway. Blood 2012, 120, 2214-2224. [CrossRef] [PubMed]

76. Heijnen, H.F.; van Wijk, R.; Pereboom, T.C.; Goos, Y.J.; Seinen, C.W.; van Oirschot, B.A.; van Dooren, R.; Gastou, M.; Giles, R.H.; van Solinge, W.; et al. Ribosomal Protein Mutations Induce Autophagy through S6 Kinase Inhibition of the Insulin Pathway. PLoS Genet. 2014, 10. [CrossRef] [PubMed]

77. Fodor, E.; Sigmond, T.; Ari, E.; Lengyel, K.; Takács-Vellai, K.; Varga, M.; Vellai, T. Methods to study autophagy in zebrafish. Methods Enzym. 2016, 587, 467-496. [CrossRef]

78. Nüsslein-Volhard, C. The zebrafish issue of Development. Development 2012, 139, 4099-4103. [CrossRef] [PubMed]

79. Klionsky, D.J.; Abdelmohsen, K.; Abe, A.; Abedin, M.J.; Abeliovich, H.; Acevedo Arozena, A.; Adachi, H.; Adams, C.M.; Adams, P.D.; Adeli, K.; et al. Guidelines for use and interpretation of assays for monitoring autophagy (3rd edition). Autophagy 2016, 12, 1-222. [CrossRef] [PubMed]

80. Yasuda, G.K.; Schubiger, G. Temporal regulation in the early embryo: Is MBT too good to be true? Trends Genet. 1992, 8, 124-127. [CrossRef]

81. Korzh, V. Before maternal-zygotic transition ... There was morphogenetic function of nuclei. Zebrafish 2009, 6, 295-302. [CrossRef] [PubMed]

82. Kimmel, C.B.; Ballard, W.W.; Kimmel, S.R.; Ullmann, B.; Schilling, T.F. Stages of embryonic development of the zebrafish. Dev. Dyn. 1995, 203, 253-310. [CrossRef] [PubMed]

83. Aanes, H.; Winata, C.L.; Lin, C.H.; Chen, J.P.; Srinivasan, K.G.; Lee, S.G.P.; Lim, A.Y.M.; Hajan, H.S.; Collas, P.; Bourque, G.; et al. Zebrafish mRNA sequencing deciphers novelties in transcriptome dynamics during maternal to zygotic transition. Genome Res. 2011, 21, 1328-1338. [CrossRef] [PubMed]

84. Benard, E.L.; Rougeot, J.; Racz, P.I.; Spaink, H.P.; Meijer, A.H. Transcriptomic Approaches in the Zebrafish Model for Tuberculosis-Insights Into Host- and Pathogen-Specific Determinants of the Innate Immune Response; Elsevier Ltd.: Amsterdam, The Netherlands, 2016; Volume 95, ISBN 9780128048009.

85. Kabeya, Y.; Mizushima, N.; Ueno, T.; Yamamoto, A.; Kirisako, T.; Noda, T.; Kominami, E.; Ohsumi, Y.; Yoshimori, T. Erratum: LC3, a mammalian homolog of yeast Apg8p, is localized in autophagosome membranes after processing (EMBO Journal (2000) 19 (5720-5728)). EMBO J. 2003, 22, 4577. [CrossRef]

86. He, C.; Bartholomew, C.R.; Zhou, W.; Klionsky, D.J. Assaying autophagic activity in transgenic GFP-Lc3 and GFP-Gabarap zebrafish embryos. Autophagy 2009, 5, 520-526. [CrossRef] [PubMed]

87. Antinucci, P.; Hindges, R. OPEN A crystal -clear zebrafish for in vivo imaging. Nat. Publ. Gr. 2016, 1-10. [CrossRef]

88. Kuma, A.; Matsui, M.; Mizushima, N. Caution in the Interpretation of LC3 Localization. Autophagy 2007, 34, 323-328. [CrossRef]

89. Tanida, I.; Yamaji, T.; Ueno, T.; Ishiura, S.; Kominami, E.; Hanada, K. Consideration about negative controls for LC3 and expression vectors for four colored fluorescent protein-LC3 negative controls. Autophagy 2008, 4, 131-134. [CrossRef] [PubMed]

90. George, A.A.; Hayden, S.; Holzhausen, L.C.; Ma, E.Y.; Suzuki, S.C.; Brockerhoff, S.E. Synaptojanin 1 is required for endolysosomal trafficking of synaptic proteins in cone photoreceptor inner segments. PLoS ONE 2014, 9. [CrossRef] [PubMed] 
91. Varga, M.; Sass, M.; Papp, D.; Takács-Vellai, K.; Kobolak, J.; Dinnyés, A.; Klionsky, D.J.; Vellai, T. Autophagy is required for zebrafish caudal fin regeneration. Cell Death Differ. 2014, 21, 547-556. [CrossRef] [PubMed]

92. Hosseini, R.; Lamers, G.E.M.; Hodzic, Z.; Meijer, A.H.; Schaaf, M.J.M.; Spaink, H.P. Correlative light and electron microscopy imaging of autophagy in a zebrafish infection model. Autophagy 2014, 10, 1844-1857. [CrossRef] [PubMed]

93. Lee, E.; Wei, Y.; Zou, Z.; Tucker, K.; Rakheja, D.; Levine, B.; Amatruda, J.F. Genetic inhibition of autophagy promotes p53 loss-ofheterozygosity and tumorigenesis. Oncotarget 2016, 7, 67919-67933. [CrossRef] [PubMed]

94. Saera-Vila, A.; Kish, P.E.; Louie, K.W.; Grzegorski, S.J.; Klionsky, D.J.; Kahana, A. Autophagy regulates cytoplasmic remodeling during cell reprogramming in a zebrafish model of muscle regeneration. Autophagy 2016, 12, 1864-1875. [CrossRef] [PubMed]

95. Cui, J.; Sim, T.H.-F.; Gong, Z.; Shen, H.-M. Generation of transgenic zebrafish with liver-specific expression of EGFP-Lc3: a new in vivo model for investigation of liver autophagy. Biochem. Biophys. Res. Commun. 2012, 422, 268-273. [CrossRef] [PubMed]

96. Kimura, S.; Noda, T.; Yoshimori, T. Dissection of the autophagosome maturation process by a novel reporter protein, tandem fluorescent-tagged LC3. Autophagy 2007, 3, 452-460. [CrossRef] [PubMed]

97. George, A.A.; Hayden, S.; Stanton, G.R.; Brockerhoff, S.E. Arf6 and the 5'phosphatase of synaptojanin 1 regulate autophagy in cone photoreceptors. BioEssays 2016, 38, S119-S135. [CrossRef] [PubMed]

98. Panic, B.; Whyte, J.R.; Munro, S.; Strochlic, T.I.; Tong, A.H.; Boone, C.; Burd, C.G.; Shemorry, A.; Varshavsky, A.; Rape, M.; et al. mTORC1 Senses Lysosomal Amino Acids. Science 2011, 678-683. [CrossRef]

99. Juhász, G. Interpretation of bafilomycin, pH neutralizing or protease inhibitor treatments in autophagic flux experiments: Novel considerations. Autophagy 2012, 8, 1875-1876. [CrossRef] [PubMed]

100. Florey, O.; Gammoh, N.; Kim, S.E.; Jiang, X.; Overholtzer, M. V-ATPase and osmotic imbalances activate endolysosomal LC3 lipidation. Autophagy 2015, 11, 88-99. [CrossRef] [PubMed]

101. Kaizuka, T.; Morishita, H.; Hama, Y.; Tsukamoto, S.; Matsui, T.; Toyota, Y.; Kodama, A.; Ishihara, T.; Mizushima, T.; Mizushima, N. An Autophagic Flux Probe that Releases an Internal Control. Mol. Cell 2016, 64, 835-849. [CrossRef] [PubMed]

102. Simonsen, A.; Tooze, S.A. Coordination of membrane events during autophagy by multiple class III PI3-kinase complexes. J. Cell Biol. 2009, 186, 773-782. [CrossRef] [PubMed]

103. Yabu, T.; Imamura, S.; Mizusawa, N.; Touhata, K.; Yamashita, M. Induction of autophagy by amino acid starvation in fish cells. Mar. Biotechnol. 2012, 14, 491-501. [CrossRef] [PubMed]

104. Jia, X.-E.; Ma, K.; Xu, T.; Gao, L.; Wu, S.; Fu, C.; Zhang, W.; Wang, Z.; Liu, K.; Dong, M.; et al. Mutation of krill causes definitive hematopoiesis failure via PERK-dependent excessive autophagy induction. Cell Res. 2015, 1-17. [CrossRef] [PubMed]

105. Schiebler, M.; Brown, K.; Hegyi, K.; Newton, S.M.; Renna, M.; Hepburn, L.; Klapholz, C.; Coulter, S.; Obregón-Henao, A.; Henao Tamayo, M.; et al. Functional drug screening reveals anticonvulsants as enhancers of mTOR-independent autophagic killing of Mycobacterium tuberculosis through inositol depletion. EMBO Mol. Med. 2015, 7, 127-139. [CrossRef] [PubMed]

106. Boglev, Y.; Badrock, A.P.; Trotter, A.J.; Du, Q.; Richardson, E.J.; Parslow, A.C.; Markmiller, S.J.; Hall, N.E.; De Jong-Curtain, T.A.; Ng, A.Y.; et al. Autophagy induction is a Tor- and Tp53-independent cell survival response in a zebrafish model of disrupted ribosome biogenesis. PLoS Genet. 2013, 9, e1003279. [CrossRef] [PubMed]

107. Mizushima, N.; Yoshimori, T.; Levine, B. Methods in mammalian autophagy research. Cell 2010, 140, 313-326. [CrossRef] [PubMed]

108. Lopez, A.; Lee, S.E.; Wojta, K.; Ramos, E.M.; Klein, E.; Chen, J.; Boxer, A.L.; Gorno-Tempini, M.L.; Geschwind, D.H.; Schlotawa, L.; et al. A152T tau allele causes neurodegeneration that can be ameliorated in a zebrafish model by autophagy induction. Cereb. Cortex 2017, 1128-1146. [CrossRef] [PubMed]

109. Espín-Palazón, R.; Martínez-López, A.; Roca, F.J.; López-Muñoz, A.; Tyrkalska, S.D.; Candel, S.; García-Moreno, D.; Falco, A.; Meseguer, J.; Estepa, A.; et al. TNF $\alpha$ Impairs Rhabdoviral Clearance by Inhibiting the Host Autophagic Antiviral Response. PLoS Pathog. 2016, 12, 1-20. [CrossRef] [PubMed]

110. Link, V.; Shevchenko, A.; Heisenberg, C.-P. Proteomics of early zebrafish embryos. BMC Dev. Biol. $2006,6,1$. [CrossRef] [PubMed] 
111. Zhang, Y.; Nguyen, D.T.; Olzomer, E.M.; Poon, G.P.; Cole, N.J.; Puvanendran, A.; Phillips, B.R.; Hesselson, D. Rescue of Pink1 Deficiency by Stress-Dependent Activation of Autophagy. Cell Chem. Biol. 2017, 1-10. [CrossRef] [PubMed]

112. Zhu, P.; Sieben, C.J.; Xu, X.; Harris, P.C.; Lin, X. Autophagy activators suppress cystogenesis in an autosomal dominant polycystic kidney disease model. Hum. Mol. Genet. 2016, 26, ddw376. [CrossRef] [PubMed]

113. Ruparelia, A.A.; Oorschot, V.; Ramm, G.; Bryson-Richardson, R.J. FLNC myofibrillar myopathy results from impaired autophagy and protein insufficiency. Hum. Mol. Genet. 2016, 25, 2131-2142. [CrossRef] [PubMed]

114. Moreau, K.; Fleming, A.; Imarisio, S.; Lopez Ramirez, A.; Mercer, J.L.; Jimenez-Sanchez, M.; Bento, C.F.; Puri, C.; Zavodszky, E.; Siddiqi, F.; et al. PICALM modulates autophagy activity and tau accumulation. Nat. Commun. 2014, 5, 4998. [CrossRef] [PubMed]

115. Catalina-Rodriguez, O.; Kolukula, V.K.; Tomita, Y.; Preet, A.; Palmieri, F.; Wellstein, A.; Byers, S.; Giaccia, A.J.; Glasgow, E.; Albanese, C.; et al. The mitochondrial citrate transporter, CIC, is essential for mitochondrial homeostasis. Oncotarget 2012, 3, 1220-1235. [CrossRef] [PubMed]

116. Ding, Y.; Sun, X.; Huang, W.; Hoage, T.; Redfield, M.; Kushwaha, S.; Sivasubbu, S.; Lin, X.; Ekker, S.; Xu, X. Haploinsufficiency of target of rapamycin attenuates cardiomyopathies in adult zebrafish. Circ. Res. 2011, 109, 658-669. [CrossRef] [PubMed]

117. Bühler, A.; Kustermann, M.; Bummer, T.; Rottbauer, W.; Sandri, M.; Just, S. Atrogin-1 deficiency leads to myopathy and heart failure in zebrafish. Int. J. Mol. Sci. 2016, 17, 187. [CrossRef] [PubMed]

118. Zheng, Q.; Wang, Q.; Wang, S.; Wu, J.; Gao, Q.; Liu, W. Thiopeptide Antibiotics Exhibit a Dual Mode of Action against Intracellular Pathogens by Affecting Both Host and Microbe. Chem. Biol. 2015, 22, 1002-1007. [CrossRef] [PubMed]

119. Wu, S.; Wang, L.; Li, J.; Xu, G.; He, M.; Li, Y.; Huang, R. Salmonella spv locus suppresses host innate immune responses to bacterial infection. Fish Shellfish Immunol. 2016, 58, 387-396. [CrossRef] [PubMed]

120. Li, Y.Y.; Wang, T.; Gao, S.; Xu, G.M.; Niu, H.; Huang, R.; Wu, S.Y. Salmonella plasmid virulence gene spvB enhances bacterial virulence by inhibiting autophagy in a zebrafish infection model. Fish Shellfish Immunol. 2016, 49, 252-259. [CrossRef] [PubMed]

121. Slade, L.; Cowie, A.; Martynuik, C.J.; Kienesberger, P.C.; Pulinilkunnil, T. Dieldrin augments mTOR signaling and inhibits lysosomal acidification in the adult zebrafish heart (Danio rerio). J. Pharmacol. Exp. Ther. 2017. [CrossRef] [PubMed]

122. Eskelinen, E.L.; Reggiori, F.; Baba, M.; Kovacs, A.L.; Seglen, P.O. Seeing is believing: The impact of electron microscopy on autophagy research. Autophagy 2011, 7, 935-956. [CrossRef] [PubMed]

123. Lucocq, J.M.; Hacker, C. Cutting a fine figure: On the use of thin sections in electron microscopy to quantify autophagy. Autophagy 2013, 9, 1443-1448. [CrossRef] [PubMed]

124. Varga, M.; Fodor, E.; Vellai, T. Autophagy in zebrafish. Methods 2015, 75, 172-180. [CrossRef] [PubMed]

125. Papp, D.; Kovács, T.; Billes, V.; Varga, M.; Tarnóci, A.; Hackler, L., Jr.; Puskás, L.G.; Liliom, H.; Tárnok, K.; Schlett, K.; et al. AUTEN-67, an autophagy-enhancing drug candidate with potent antiaging and neuroprotective effects. Autophagy 2016, 12, 273-286. [CrossRef] [PubMed]

126. Clark, S.L. Cellular differentiation in the kidneys of newborn mice studies with the electron microscope. J. Biophys. Biochem. Cytol. 1957, 3, 349-362. [CrossRef] [PubMed]

127. Novikoff, A.B. The proximal tubule cell in experimental hydronephrosis. J. Biophys. Biochem. Cytol. 1959, 6, 136-138. [CrossRef] [PubMed]

128. Kim, I.; Rodriguez-Enriquez, S.; Lemasters, J.J. Selective degradation of mitochondria by mitophagy. Arch. Biochem. Biophys. 2007, 462, 245-253. [CrossRef] [PubMed]

129. Kiššová, I.; Deffieu, M.; Manon, S.; Camougrand, N. Uth1p is involved in the autophagic degradation of mitochondria. J. Biol. Chem. 2004, 279, 39068-39074. [CrossRef] [PubMed]

130. Tal, R.; Winter, G.; Ecker, N.; Klionsky, D.J.; Abeliovich, H. Aup1p, a yeast mitochondrial protein phosphatase homolog, is required for efficient stationary phase mitophagy and cell survival. J. Biol. Chem. 2007, 282, 5617-5624. [CrossRef] [PubMed]

131. Matic, I.; Strobbe, D.; Di Guglielmo, F.; Campanella, M. Molecular Biology Digest of Cell Mitophagy, 1st ed.; Elsevier Inc.: Amsterdam, The Netherlands, 2017; Volume 332, ISBN 1937-6448.

132. Mortensen, M.; Ferguson, D.J.P.; Edelmann, M.; Kessler, B.; Morten, K.J.; Komatsu, M.; Simon, A.K. Loss of autophagy in erythroid cells leads to defective removal of mitochondria and severe anemia in vivo. Proc. Natl. Acad. Sci. 2010, 107, 832-837. [CrossRef] [PubMed] 
133. Zhang, J.; Randall, M.S.; Loyd, M.R.; Dorsey, F.C.; Kundu, M.; Cleveland, J.L.; Ney, P.A. Mitochondrial clearance is regulated by Atg7-dependent and -independent mechanisms during reticulocyte maturation. Blood 2009, 114, 157-164. [CrossRef] [PubMed]

134. Youle, R.J.; Narendra, D.P. Mechanisms of mitophagy. Nat. Rev. Mol. Cell Biol. 2011, 12, 9-14. [CrossRef] [PubMed]

135. Narendra, D.P.; Jin, S.M.; Tanaka, A.; Suen, D.F.; Gautier, C.A.; Shen, J.; Cookson, M.R.; Youle, R.J. PINK1 is selectively stabilized on impaired mitochondria to activate Parkin. PLoS Biol. 2010, 8. [CrossRef] [PubMed]

136. Vives-Bauza, C.; Zhou, C.; Huang, Y.; Cui, M.; De Vries, R.L. A.; Kim, J.; May, J.; Tocilescu, M.A.; Liu, W.; Ko, H.S.; et al. PINK1-dependent recruitment of Parkin to mitochondria in mitophagy. Proc. Natl. Acad. Sci. 2010, 107, 378-383. [CrossRef] [PubMed]

137. Matsuda, N.; Sato, S.; Shiba, K.; Okatsu, K.; Saisho, K.; Gautier, C.A.; Sou, Y.S.; Saiki, S.; Kawajiri, S.; Sato, F.; et al. PINK1 stabilized by mitochondrial depolarization recruits Parkin to damaged mitochondria and activates latent Parkin for mitophagy. J. Cell Biol. 2010, 189, 211-221. [CrossRef] [PubMed]

138. Ding, W.X.; Ni, H.M.; Li, M.; Liao, Y.; Chen, X.; Stolz, D.B.; Dorn, G.W.; Yin, X.M. Nix is critical to two distinct phases of mitophagy, reactive oxygen species-mediated autophagy induction and Parkin-ubiquitin-p62-mediated mitochondrial priming. J. Biol. Chem. 2010, 285, 27879-27890. [CrossRef] [PubMed]

139. Schapira, A.H. Mitochondria in the aetiology and pathogenesis of Parkinson's disease. Lancet Neurol. 2008, 7, 97-109. [CrossRef]

140. Anichtchik, O.; Diekmann, H.; Fleming, A.; Roach, A.; Goldsmith, P.; Rubinsztein, D.C. Loss of PINK1 Function Affects Development and Results in Neurodegeneration in Zebrafish. J. Neurosci. 2008, 28, 8199-8207. [CrossRef] [PubMed]

141. Flinn, L.; Mortiboys, H.; Volkmann, K.; Kster, R.W.; Ingham, P.W.; Bandmann, O. Complex i deficiency and dopaminergic neuronal cell loss in parkin-deficient zebrafish (Danio rerio). Brain 2009, 132, 1613-1623. [CrossRef] [PubMed]

142. Flinn, L.J.; Keatinge, M.; Bretaud, S.; Mortiboys, H.; Matsui, H.; De Felice, E.; Woodroof, H.I.; Brown, L.; McTighe, A.; Soellner, R.; et al. TigarB causes mitochondrial dysfunction and neuronal loss in PINK1 deficiency. Ann. Neurol. 2013, 74, 837-847. [CrossRef] [PubMed]

143. Wager, K.; Russell, C. Mitophagy and neurodegeneration: The zebrafish model system. Autophagy 2013, 9, 1693-1709. [CrossRef] [PubMed]

144. Plucińska, G.B. In Vivo Imaging of the Mitochondrial Life-Cycle in Zebrafish. PhD Thesis, University Library of the Technical University of Munich, Munich, Germany, 2014.

145. Hyttinen, J.M.T.; Amadio, M.; Viiri, J.; Pascale, A.; Salminen, A.; Kaarniranta, K. Clearance of misfolded and aggregated proteins by aggrephagy and implications for aggregation diseases. Ageing Res. Rev. 2014, 18, 16-28. [CrossRef] [PubMed]

146. Dikic, I. Proteasomal and Autophagic Degradation Systems. Annu. Rev. Biochem. 2017, 86, $193-224$. [CrossRef] [PubMed]

147. Williams, A.; Sarkar, S.; Cuddon, P.; Ttofi, E.K.; Siddiqi, F.H.; Jahreiss, L.; Fleming, A.; Pask, D.; Kane, C.J. O.; Floto, R.A.; et al. UKPMC Funders Group Novel targets for Huntington's disease in an mTOR-independent autophagy pathway. Nat. Chem. Biol. 2009, 4, 295-305. [CrossRef] [PubMed]

148. Underwood, B.R.; Imarisio, S.; Fleming, A.; Rose, C.; Krishna, G.; Heard, P.; Quick, M.; Korolchuk, V.I.; Renna, M.; Sarkar, S.; et al. Antioxidants can inhibit basal autophagy and enhance neurodegeneration in models of polyglutamine disease. Hum. Mol. Genet. 2010, 19, 3413-3429. [CrossRef] [PubMed]

149. Miller, S.E.; Sahlender, D.A.; Graham, S.C.; Höning, S.; Robinson, M.S.; Peden, A.A.; Owen, D.J. The molecular basis for the endocytosis of small R-SNAREs by the clathrin adaptor CALM. Cell 2011, 147, 1118-1131. [CrossRef] [PubMed]

150. Arndt, V.; Dick, N.; Tawo, R.; Dreiseidler, M.; Wenzel, D.; Hesse, M.; Fürst, D.O.; Saftig, P.; Saint, R.; Fleischmann, B.K.; et al. Chaperone-Assisted Selective Autophagy Is Essential for Muscle Maintenance. Curr. Biol. 2010, 20, 143-148. [CrossRef] [PubMed]

151. Nakagawa, I. Autophagy Defends Cells Against Invading Group A Streptococcus. Science 2004, 306, 1037-1040. [CrossRef] [PubMed] 
152. Gutierrez, M.G.; Master, S.S.; Singh, S.B.; Taylor, G.A.; Colombo, M.I.; Deretic, V. Autophagy is a defense mechanism inhibiting BCG and Mycobacterium tuberculosis survival in infected macrophages. Cell 2004, 119, 753-766. [CrossRef] [PubMed]

153. Huang, J.; Brumell, J.H. Bacteria-autophagy interplay: a battle for survival. Nat. Rev. Microbiol. 2014, 12, 101-114. [CrossRef] [PubMed]

154. Mehta, P.; Henault, J.; Kolbeck, R.; Sanjuan, M.A. Noncanonical autophagy: One small step for LC3, one giant leap for immunity. Curr. Opin. Immunol. 2014, 26, 69-75. [CrossRef] [PubMed]

155. Kohler, L.J.; Roy, C.R. Autophagic targeting and avoidance in intracellular bacterial infections. Curr. Opin. Microbiol. 2017, 35, 36-41. [CrossRef] [PubMed]

156. Sprenkeler, E.G.G.; Gresnigt, M.S.; van de Veerdonk, F.L. LC3-associated phagocytosis: a crucial mechanism for antifungal host defence against Aspergillus fumigatus. Cell. Microbiol. 2016, 18, 1208-1216. [CrossRef] [PubMed]

157. Mohanty, S.; Jagannathan, L.; Ganguli, G.; Padhi, A.; Roy, D.; Alaridah, N.; Saha, P.; Nongthomba, U.; Godaly, G.; Gopal, R.K.; et al. A mycobacterial phosphoribosyltransferase promotes bacillary survival by inhibiting oxidative stress and autophagy pathways in macrophages and zebrafish. J. Biol. Chem. 2015, 290, 13321-13343. [CrossRef] [PubMed]

158. Mazon Moya, M.J.; Colucci-Guyon, E.; Mostowy, S. Use of Shigella flexneri to study autophagy-cytoskeleton interactions. J. Vis. Exp. 2014, 1-11. [CrossRef] [PubMed]

159. Torraca, V.; Mostowy, S. Septins and Bacterial Infection. Front. Cell Dev. Biol. 2016, 4, 1-8. [CrossRef] [PubMed]

160. Meijer, A.H.; Van Der Vaart, M. DRAM1 promotes the targeting of mycobacteria to selective autophagy. Autophagy 2014, 10, 2389-2391. [CrossRef] [PubMed]

161. Crighton, D.; Wilkinson, S.; O’Prey, J.; Syed, N.; Smith, P.; Harrison, P.R.; Gasco, M.; Garrone, O.; Crook, T.; Ryan, K.M. DRAM, a p53-Induced Modulator of Autophagy, Is Critical for Apoptosis. Cell 2006, 126, 121-134. [CrossRef] [PubMed]

162. Kim, J.K.; Lee, H.M.; Park, K.S.; Shin, D.M.; Kim, T.S.; Kim, Y.S.; Suh, H.W.; Kim, S.Y.; Kim, I.S.; Kim, J.M.; et al. MIR144* inhibits antimicrobial responses against Mycobacterium tuberculosis in human monocytes and macrophages by targeting the autophagy protein DRAM2. Autophagy 2017, 13, 423-441. [CrossRef] [PubMed]

163. Masud, S.; Torraca, V.; Meijer, A.H. Modeling Infectious Diseases in the Context of a Developing Immune System. Curr. Top. Dev. Biol. 2016, 124, 277-329. [CrossRef] [PubMed] 